\title{
Ki-67: level of evidence and methodological considerations for its role in the clinical management of breast cancer: analytical and critical review
}

\author{
Elisabeth Luporsi • Fabrice André • Frédérique Spyratos • Pierre-Marie Martin • \\ Jocelyne Jacquemier • Frédérique Penault-Llorca • Nicole Tubiana-Mathieu • \\ Brigitte Sigal-Zafrani • Laurent Arnould • Anne Gompel • Caroline Egele • \\ Bruno Poulet $\cdot$ Krishna B. Clough $\cdot$ Hubert Crouet $\cdot$ Alain Fourquet $\cdot$ Jean-Pierre Lefranc \\ Carole Mathelin • Nicolas Rouyer • Daniel Serin • Marc Spielmann • Margaret Haugh • \\ Marie-Pierre Chenard $\cdot$ Etienne Brain $\cdot$ Patricia de Cremoux $\cdot$ Jean-Pierre Bellocq
}

Received: 11 October 2011/ Accepted: 12 October 2011/Published online: 3 November 2011

(C) Springer Science+Business Media, LLC. 2011

\begin{abstract}
Clinicians can use biomarkers to guide therapeutic decisions in estrogen receptor positive $(\mathrm{ER}+)$ breast cancer. One such biomarker is cellular proliferation as evaluated by Ki-67. This biomarker has been extensively studied and is easily assayed by histopathologists but it is not currently accepted as a standard. This review focuses on its prognostic and predictive value, and on methodological considerations for its measurement and the cutpoints used for treatment decision. Data describing study
\end{abstract}

\section{E. Luporsi $(\bowtie)$}

INSERM, Centre d'Investigations Cliniques-9501, CHU Nancy

\& Nancy-Université, 54511 Vandoeuvre-les-Nancy, France

e-mail: e.luporsi@nancy.unicancer.fr

F. André · M. Spielmann

Department of Oncology, Institut Gustave Roussy, Villejuif,

France

F. Spyratos

Laboratory of Oncogenetics, Institut Curie-Hôpital René

Huguenin, St-Cloud, France

P.-M. Martin

Translational Laboratory-Biological Oncology, AP-HM,

Marseille, France

J. Jacquemier

Department of Bio-Pathology, Institut Paoli-Calmettes,

Marseille, France

F. Penault-Llorca

Department of Pathology, Centre Jean Perrin and EA 4233,

University of Auvergne, Clermont-Ferrand, France

N. Tubiana-Mathieu

Department of Medical Oncology, CHU Dupuytren, Limoges, France design, patients' characteristics, methods used and results were extracted from papers published between January 1990 and July 2010. In addition, the studies were assessed using the REMARK tool. Ki-67 is an independent prognostic factor for disease-free survival (HR 1.05-1.72) in multivariate analyses studies using samples from randomized clinical trials with secondary central analysis of the biomarker. The level of evidence (LOE) was judged to be I-B with the recently revised definition of Simon. However,

\author{
B. Sigal-Zafrani \\ Department of Pathology, Institut Curie, Paris, France
}

L. Arnould

Department of Tumour Biology and Pathology, Centre GeorgesFrançois Leclerc, Dijon, France

A. Gompel

Unit of Gynaecology, Université Paris Descartes, INSERM

UMRS 938, Hôtel-Dieu, AP-HP, Paris, France

C. Egele · M.-P. Chenard · J.-P. Bellocq $(\bowtie)$

Département de Pathologie, Hôpital de Hautepierre, Hôpitaux

Universitaires de Strasbourg, 1 Avenue Molière, 67098

Strasbourg Cedex, France

e-mail: jean-pierre.bellocq@chru-strasbourg.fr

B. Poulet

Institut de Pathologie de Paris, 49 rue du Ranelagh, 75016 Paris, France

K. B. Clough

Department of Surgery, L'Institut du Sein/Paris Breast Center, Paris, France

H. Crouet

Department of Surgical Oncology, Centre Francois Baclesse, Caen, France 
standardization of the techniques and scoring methods are needed for the integration of this biomarker in everyday practice. Ki-67 was not found to be predictive for longterm follow-up after chemotherapy. Nevertheless, high KI67 was found to be associated with immediate pathological complete response in the neoadjuvant setting, with an LOE of II-B. The REMARK score improved over time (with a range of $6-13 / 20$ vs. 10-18/20, before and after 2005, respectively). KI-67 could be considered as a prognostic biomarker for therapeutic decision. It is assessed with a simple assay that could be standardized. However, international guidelines are needed for routine clinical use.

Keywords Breast cancer $\cdot \mathrm{Ki}-67$. Predictive factor . Prognostic factor

\section{Introduction}

Both adjuvant, and neoadjuvant chemotherapy and hormonal treatment have made a major contribution to improving disease-free survival (DFS) and overall survival (OS) in breast cancer [38, 50, 83, 103]. When physicians prescribe, they consider the risk-to-benefit ratio associated with a given therapy for a specific patient because the

\footnotetext{
A. Fourquet

Department of Oncological Radiotherapy, Institut Curie, Paris, France

J.-P. Lefranc

Department of Gynaecological and Breast Cancer Surgery, PitiéSalpêtrière, AP-HP, Paris, France

C. Mathelin

Department of Gynaecology \& Obstetrics, University Hospital, Strasbourg, France

N. Rouyer

Laboratory of Pathology, SELARL DIAG, Nice, France

D. Serin

Department of Medical Oncology, Institute Sainte Catherine, Avignon, France

M. Haugh

MediCom Consult, 39 rue Clément Michut, 69100 Villeurbanne, France

e-mail: mhaugh@medicom-consult.com

E. Brain

Department of Medical Oncology, Institut Curie-Hôpital René Huguenin, St-Cloud, France

P. de Cremoux

Department of Tumour Biology, Hôpital Saint-Louis, AP-HP,

Paris, France
}

therapies have high toxicities. To guide therapeutic decisions, physicians use clinical, histopathological variables and biomarkers as prognostic or predictive tools, these latter being most effective if linked with targeted therapies (companion diagnostics), such as estrogen receptor (ER) and human epidermal growth factor receptor 2 (HER2) [35, 85, 106].

The first aim of this systematic review was to evaluate the level of evidence (LOE) for $\mathrm{Ki}-67$ as a prognostic factor or predictive factor of response to chemo- and hormonotherapy in patients with invasive breast carcinoma, and define its weight in the everyday therapeutic decisionmaking process, in particular within the ER+ tumour group in order to select women who are most likely to benefit from chemotherapy. The second aim was focused on technical and methodological aspects about the measurement of Ki-67, and on the cut-points used for treatment decision.

We report data from studies using samples from randomized clinical trials (RCTs), cohort studies, case-control studies, and we also summarize the results of systematic and narrative reviews. We paid particular attention to the methodological aspects of the studies. We took into account the recommendations published in 2008 by the National Academy of Clinical Biochemistry and elaborated by an international panel of experts, which agreed with those proposed by the ASCO guidelines and complement them, in particular by their analysis of data related to the quality of the analytical procedures used [51, 101]. In addition, the Reporting Recommendations for Tumor Marker Prognostic Studies (REMARK) score was used to assess the quality of the reporting of the prognostic study results [71].

Recently it has been claimed that results from commercially available genomic profiling tests (i.e. Mammaprint $^{\mathrm{TM}}$, Oncotype $\mathrm{DX}^{\circledR}$ ) can predict which patients should receive therapy. Several genes coding for proliferation factors, a key biological driver, are targeted in these genomic profiling tests [12, 26, 58, 112, 113]. Moreover, recent tests, e.g. MapQuant $\mathrm{Dx}^{\mathrm{TM}}$ genomic grade and THEROS BCI ${ }^{\circledR}$ have been developed to assess tumour grade molecularly since proliferation is a major component of tumour grade [113]. Nevertheless, it remains uncertain if these available genomic profiling tests have significant added value when compared with the histopathological assessment of ER, HER2 and Ki-67, the latter being routinely used as a marker of proliferation, although not yet as a standard, in breast cancer [25, 113].

$\mathrm{Ki}-67$ protein is detected during all the active phases of the cell cycle, but is absent in resting cells [65]. Since its discovery in the early 1980s, there has been interest in the role of $\mathrm{Ki}-67$ as a proliferation marker in cancer, 
particularly lymphomas, breast, endocrine and brain cancers. It is commonly used as a complement to grading systems that include mitotic counting as a sign of proliferation. Initially, immunohistochemical detection was performed on frozen tissues as the available antibodies had lower affinity on fixed tissues. Antibodies that are currently available can provide sufficiently intense immunostaining on paraffin sections, making the test more feasible [61]. Interestingly, $\mathrm{Ki}-67$ is one of the five genes of proliferation that contributes an importance weight to the Oncotype score, out of 16 cancer-associated genes [79].

\section{Methods}

We searched PubMed to identify prospective or retrospective studies reporting results from analyses of Ki-67 as either a prognostic factor or a predictive factor in women with breast cancer. The terms used for searching were divided into three groups to identify references on: breast cancer and its treatment, $\mathrm{Ki}-67$ and the types of studies (Appendix 1). These were combined into a search strategy that was limited to publications in English from 1 January 1990 to 31 July 2010. The titles and abstracts of the references identified by this search strategy were screened by two methodologists independently. The reference lists of included studies were scanned to identify additional references.

The outcomes of interest for the prognostic studies that had to be present for inclusion of the study were OS or DFS. In the predictive studies, the outcomes of interest were clinical or pathological partial or complete response.

\section{Data extracted}

The items that were extracted from each publication are listed in Appendix 2. The working group validated and agreed on the interpretation of the data and assigned the LOE using the recently revised definition (Table 1) [98]. The REMARK 20-item guideline was used to assess the quality of the reporting in the prognostic studies identified, only for RCTs. Items included were: the description of patients; specimen characteristics; assay methods; study design; statistical analysis methods; presentation of results and study objectives and pre-specified hypotheses [71].

\section{Results}

After screening the 314 references identified by the search strategy, 71 were included in this review (Fig. 1). The main reason for exclusion was the type of breast cancer (ductal carcinoma in situ). Details from the studies, including tumour characteristics, treatment regimen, Ki-67 analysis modalities are reported in Table 2.

\section{Samples from randomised clinical trials}

We identified 17 studies that analysed samples from patients that had been included in RCTs in neoadjuvant and adjuvant setting $[5,6,11,13,20,29,32-35,37,39,40,46$, $60,66,69,70,72,77,83,91,99,108-110]$. Ki-67 was assessed as a prognostic factor for 9,185 patients in ten studies (three with neoadjuvant treatment and seven with adjuvant treatment), both as a prognostic and predictive

Table 1 Summary of definitions of LOE [98]

\begin{tabular}{|c|c|c|}
\hline LOE & Type of study & Validation \\
\hline I-A & $\begin{array}{l}\text { RCT specifically to assess the utility of the biomarker. The samples } \\
\text { are collected and analysed in real-time }\end{array}$ & Not necessary but could be useful \\
\hline I-B & $\begin{array}{l}\text { RCT not specifically to assess the utility of the biomarker. The samples } \\
\text { are stored during the study and analysed after the study is finished, } \\
\text { following a protocol }\end{array}$ & One or more studies with consistent results \\
\hline II-B & $\begin{array}{l}\text { RCT not specifically to assess the utility of the biomarker. The samples } \\
\text { are stored during the study and analysed after the study is finished, } \\
\text { following a protocol }\end{array}$ & $\begin{array}{l}\text { Only one study, or several studies with inconsistent } \\
\text { results }\end{array}$ \\
\hline II-C & $\begin{array}{l}\text { Non-randomized retrospective study aimed to assess the utility } \\
\text { of the biomarker using samples from patients in an observational setting } \\
\text { (standard treatment and follow-up) }\end{array}$ & Two or more studies with consistent results \\
\hline III-C & $\begin{array}{l}\text { Non-randomized retrospective study aimed to assess the utility } \\
\text { of the biomarker using samples from patients in an observational setting } \\
\text { (standard treatment and follow-up) }\end{array}$ & $\begin{array}{l}\text { Only one study, or several studies with inconsistent } \\
\text { results }\end{array}$ \\
\hline IV-V-D & No aspect of the study is prospective & $\begin{array}{l}\text { Not necessary because these types of studies } \\
\text { do not enable the clinical utility of the biomarker } \\
\text { to be assessed }\end{array}$ \\
\hline
\end{tabular}




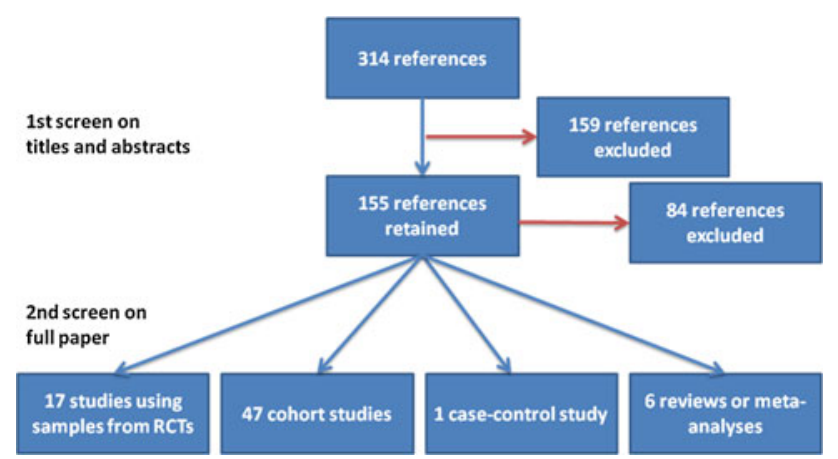

Fig. 1 Summary from the literature search

factors in three studies involving 411 patients (all with neoadjuvant treatment) and as a predictive factor in four studies involving 520 patients (all with neoadjuvant treatment).

In the majority of studies with $\mathrm{Ki}-67$ as a prognostic factor, both node negative ( $\mathrm{pN} 0)$ and node-positive $(\mathrm{pN}+)$ patients were included. In the univariate analyses the hazard ratio (HR) for DFS ranged from 1.06 to 2.09. Ki-67 remained an independent prognostic factor in multivariate analyses in seven studies (HR 1.05-1.72). Despite the differences in the methodologies used, particularly the cutpoint for Ki-67, the HR values were consistent.

Only five studies used OS as a primary objective to evaluate $\mathrm{Ki}-67$, and one analysed breast cancer-specific survival (BCSS). In the studies with OS, Ki-67 was a statistically significant prognostic factor (HR 1.11-1.83) in univariate analyses; this was not reported for the trial with BCSS as the outcome. Multivariate analyses were reported for four trials and $\mathrm{Ki}-67$ was an independent prognostic factor in only one trial with OS; it was also significant in the study with BCSS.

The REMARK score for these studies ranged from 9 to 18 (on a scale from 0 to 20), with a median of 12 and a mean of 12.8. The LOE for $\mathrm{Ki}-67$ as a prognostic factor for DFS (Table 1) was judged to be I-B since the results were consistent across several studies, done using material from randomized trials and with centralized slide review.

Among the seven studies that evaluated $\mathrm{Ki}-67$ as a predictive factor, either solely or also as prognostic factor, three studies assessed the response to neoadjuvant chemotherapy [20, 60, 66, 70], one assessed neoadjuvant hormonotherapy [32-35, 99], and three assessed neoadjuvant chemotherapy and hormonotherapy [13, 46, 110]. Only one study [46] concluded that elevated Ki-67 was predictive of response to chemotherapy; therefore, the LOE for $\mathrm{Ki}-67$ as a predictive factor was judged to be IIB.

The trials assessing the predictive value of $\mathrm{Ki}-67$ in and adjuvant setting evaluated either first generation adjuvant chemotherapy versus no treatment, or compared an optimal versus sub-optimal regimen. In the IBCSG VIII/IX trial, Viale et al. [109] did not detect any predictive value for $\mathrm{Ki}$ 67 for the efficacy of CMF compared with no chemotherapy. In this analysis, the $P$ values for $\mathrm{Ki}-67$ treatment interaction were 0.45 and 0.90 for IBCSG VIII and IX, respectively. In two other randomized trials comparing anthracyclines versus non anthracycline-based chemotherapy (NEAT/BR9601), no interaction between Ki-67 and the treatment arms was detected, suggesting that the treatment efficacy was not predicted by the Ki-67 level [6]. Finally, at least two studies assessed the predictive value of Ki-67 for the efficacy of docetaxel. Penault-Llorca et al. [83], using material from the PACS01 trial, reported that high Ki-67 was associated with a higher efficacy of docetaxel. However, these results are insufficient to conclude that $\mathrm{Ki}-67$ is a predictive factor.

In a study published after the literature search for this report, Dumontet et al. [36] analysed tissue specimens for prognostic and predictive factors in the BCIRG 001 trial. They concluded that Ki-67 was an independent prognostic factor in women receiving adjuvant chemotherapy for node-positive breast cancer, but was not a predictive factor for response to docetaxel. Overall, these studies suggest that Ki-67 is not predictive for chemotherapy.

Samples from cohort and case-control studies

We identified 47 cohort studies that assessed the role of Ki67 , as a prognostic factor solely (32 studies; 16,902 patient; patients received neoadjuvant treatment in one study, adjuvant treatment in 25 studies and no details of treatment were available in six studies), as a predictive factor solely (eight studies; 655 patients; patients received neoadjuvant treatment in six, adjuvant in one, and both in one study), or both as a prognostic and predictive factor (seven studies; 1,844 patients; all patients received neoadjuvant treatment) [2-4, 7-9, 14-19, 21-23, 30, 42-45, 49, 54-57, 59, 62, 63, 67, 73, 76, 78, 80-82, 84, 86-90, 92, 93, 96, 97, 104, 105]. We also identified one case-control study (828 patients) in which $\mathrm{Ki}-67$ was assessed as a predictive factor for chemotherapy [1].

About 2/3 of these studies assessing Ki-67 as a prognostic factor $(n=39)$ reported that it was an independent factor for DFS or OS or both. Of the 15 studies assessing $\mathrm{Ki}-67$ as a predictive factor, seven suggested that it may be a predictive factor for response to treatment. Most studies reported anthracycline regimen or $\mathrm{CMF}$ as chemotherapy and tamoxifen or letrozole or goserelin as hormone therapy. The unique case-control study considered that a high $\mathrm{Ki}-67$ value (71-100\%) was independently predictive of benefit from adjuvant chemotherapy treatment [HR for $\mathrm{BCSS}=0.35(95 \% \mathrm{CI}=0.18-0.69), P=0.003]$. 
Meta-analyses

Although the two meta-analyses were published within a year of each other, they did not include the same studies (with 57 and $60 \%$ overlapping, respectively); the statistical methods used were also different (Tables 3, 4; Fig. 2) [27, 100]. Neither of these meta-analyses differentiated if the tissue samples came from randomised controlled trials or case-control or cohort studies.

In the meta-analysis published by de Azambuja et al. in 2007 [27], the prognostic value of $\mathrm{Ki}-67$ was reported only in univariate analyses for both DFS and OS. In the analysis for DFS, they collected data from 38 studies (including 10,954 patients) and found a HR of 1.88 (1.75-2.02) with a fixed effect model, but with significant between-study heterogeneity (design, type of patients and results). In the analysis for OS concerning 35 studies (including 9,472 patients) they found a HR of 1.89 (1.74-2.06), also with a fixed effect model and significant between-study heterogeneity. In sub-analyses, similar results were observed, but no heterogeneity was found for $\mathrm{pN}+$ patients or for untreated patients (pN0 for DFS and $\mathrm{pN} 0 / \mathrm{pN}+$ for $\mathrm{OS}$ ).

In the meta-analysis of Stuart-Harris et al. in 2008 [100], after adjustment for probable publication bias, a high level of Ki-67 was associated with poor DFS and OS and this remained statistically significant in multivariate analyses. The pooled adjusted HRs were 2.05 (1.80-2.33) and 1.88 (1.55-2.27) for DFS and OS in univariate analyses, and $1.76(1.56-1.98)$ and $1.42(1.14-1.77)$ in multivariate analyses, respectively. In the analyses for DFS, there were no evidence of significant between-study heterogeneity, but this was not the case for OS.

The authors in both these meta-analyses acknowledged that the included studies used different eligibility criteria, study design, methods for measuring Ki-67 and cut-point values. Despite the differences, the results are consistent, and thus reinforce the value of $\mathrm{Ki}-67$ as a prognostic factor.

\section{Narrative reviews}

Four narrative reviews were identified [24, 107, 111, 115]. None of these reviews assessed the predictive value of $\mathrm{Ki}$ 67. Two of them, Weigel and Dowsett [111] and Yerushalmi et al. [115] summarized the results from the metaanalyses described above. Colozza et al. [24] who looked at several markers included 15 studies (5,137 patients) for $\mathrm{Ki}$ 67. They concluded that Ki-67 was a statistically significant prognostic factor but not a standard one at present, due to the lack of standardization for pre-analytical steps, staining procedures and scoring methods. Urruticoechea et al. [107] reviewed 40 trials, involving more than 11,000 patients). They found strong evidence that Ki-67 was a prognostic factor for $\mathrm{pN} 0$ patients in univariate analyses, and that it remained significant in multivariate analyses. In the studies with $\mathrm{pN}+$ patients or mixed $\mathrm{pN} 0 / \mathrm{pN}+$ patients, the results were less clear, although one study concluded that $\mathrm{Ki}-67$ was a candidate biomarker for predicting docetaxel efficacy in $\mathrm{ER}+, \mathrm{pN}+$ breast cancer [83].

\section{Discussion}

Early detection and improvements in systemic neoadjuvant and adjuvant therapies explain the observed decrease in mortality in breast cancer [53]. However, since chemotherapy is associated with adverse effects, it is important to be able to tailor treatment strategies for each patient. Companion diagnostic tests, such as HER2 or ER measurements, which are by essence predictive, are already key actors in daily therapeutic strategies. In parallel, nonassociated tests, such as proliferation biomarkers, continue to be investigated in the hope of finding reliable tools to help to identify those women who are most likely to benefit from chemotherapy.

Ki-67 was significantly associated with DFS in multivariate analyses in seven RCTs and two meta-analyses with consistent HRs or relative risks (RRs) [27, 29, 32-35, 39, 40, 83, 99, 100, 108, 109]. Although, more heterogeneous, similar results were reported in studies using samples from cohort studies. The HRs and RRs reported for $\mathrm{Ki}-67$ in most of these studies were within the same ranges as those found for other validated prognostic markers (ER, HER2, uPA, node status, histological grade) (Table 5) [10, 64, 94, 100, 113].

The evidence reviewed here, with consistent results between the studies allowing the attribution of an LOE I-B, validates the use of $\mathrm{Ki}-67$ as a prognostic factor for DFS in patients receiving adjuvant therapy. As none of the studies were specifically designed to assess $\mathrm{Ki}-67$ as a prognostic factor, the LOE cannot be I-A. A LOE I defines a marker that is ready for clinical use, therefore, justifying its status as a biomarker as suggested by Diamandis [31]. This level is based on the hierarchical classification for medical utility of a biomarker proposed by Simon et al. in 2009 [98], an updated revision of the initial classification proposed by Hayes et al. in 1996 [52]. This differs dramatically from the LOE proposed by Colozza et al. [24] who suggested a level III or even IV. However, it should be emphasised that our conclusion is based on results from studies using samples from RCTs with central review of the marker; that was not the case in the review conducted by Colozza et al. that included studies published before 2004. This implies that standardization of the techniques and counting methods ensuring efficient and practical alternatives to centralized testing (i.e. automated staining and image analysis) will be necessary for everyday practice. 


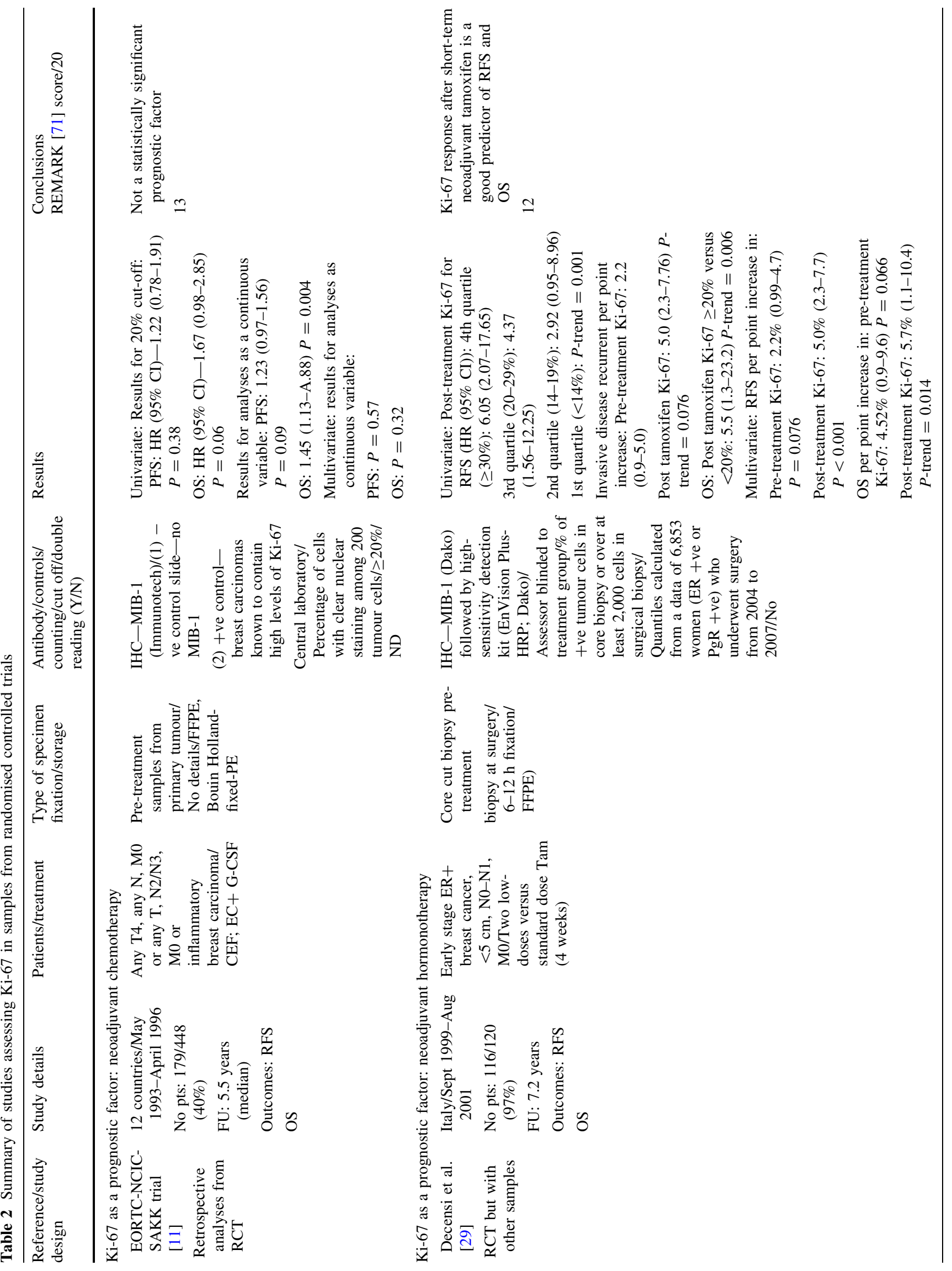




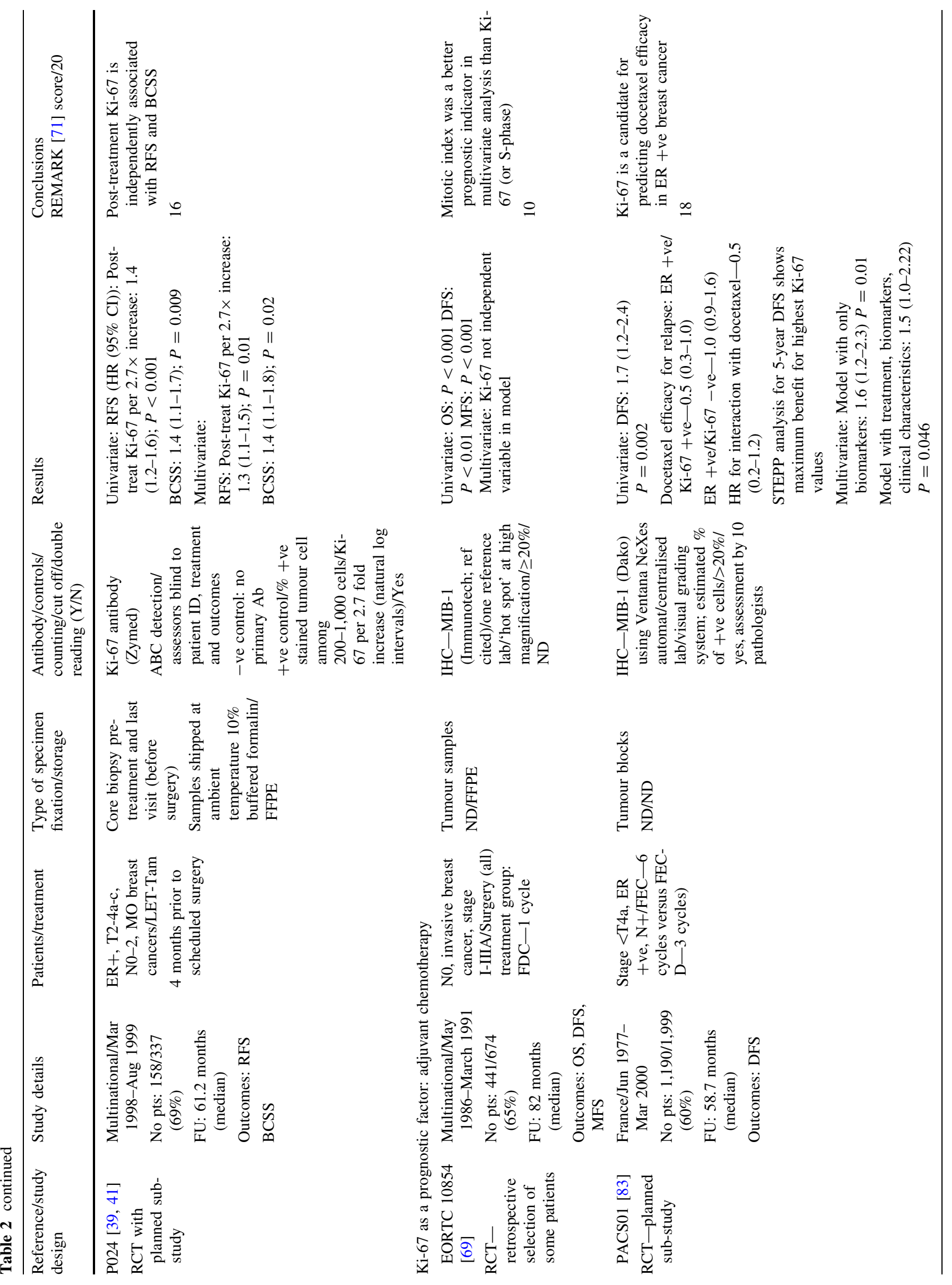




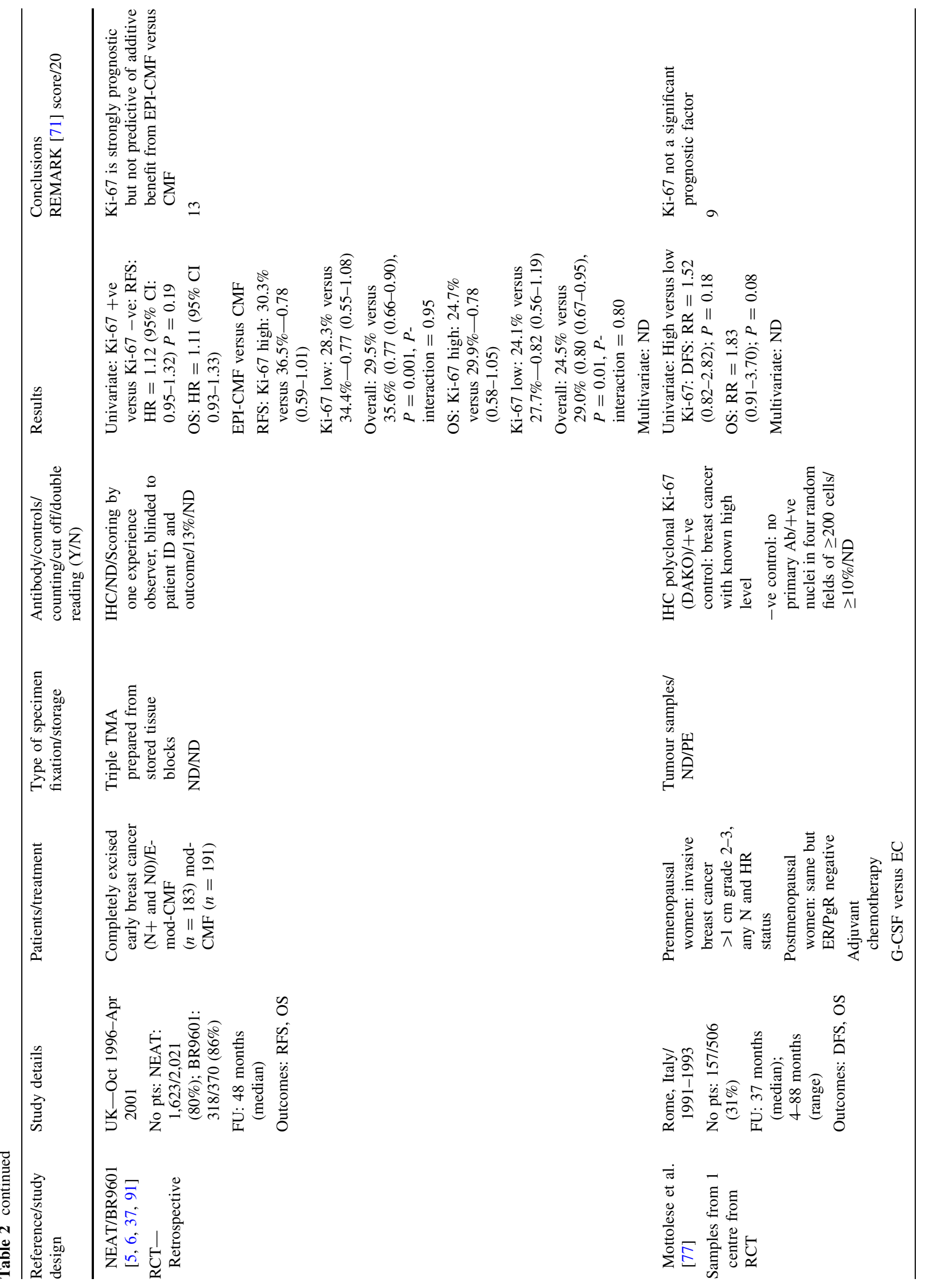




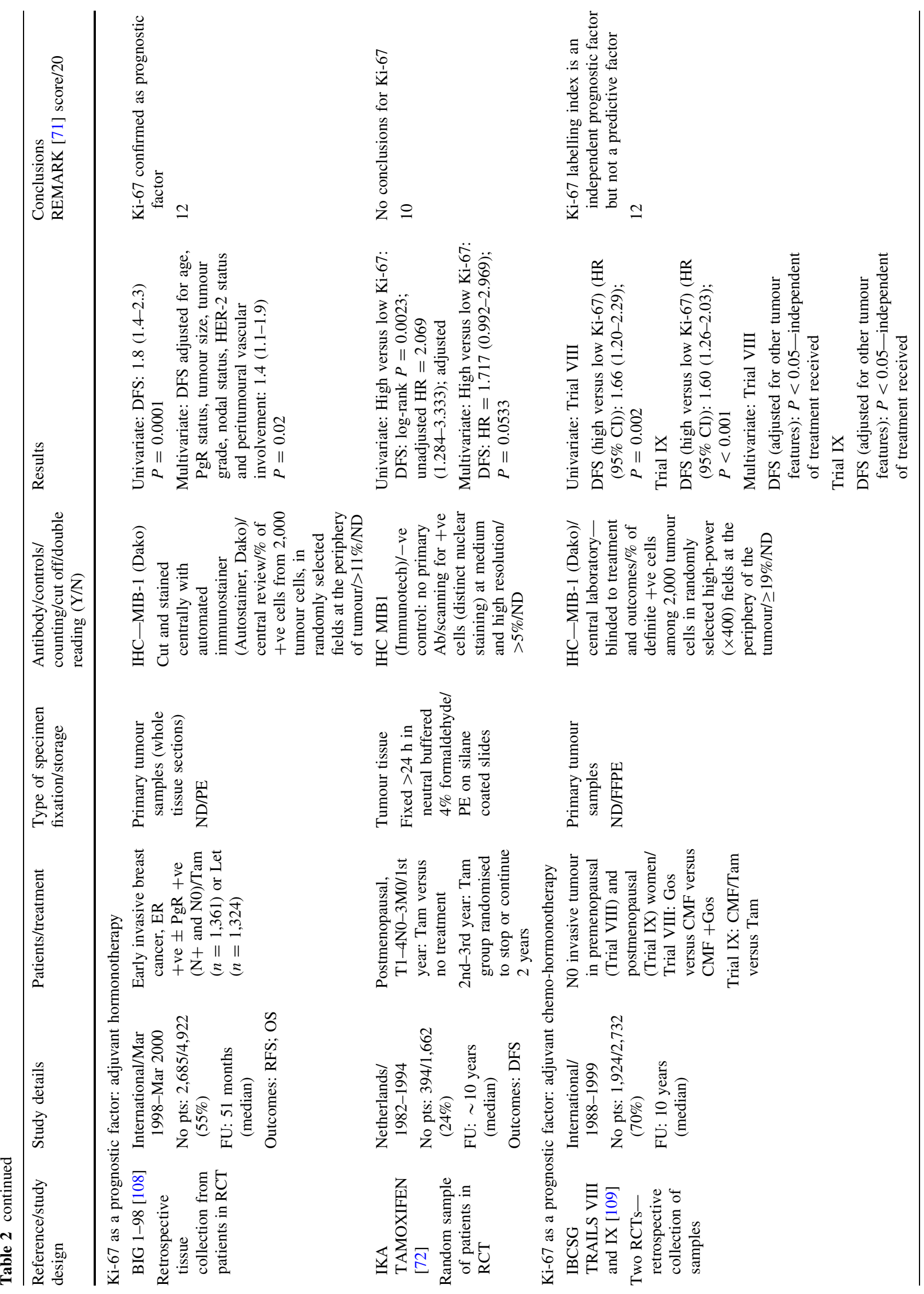




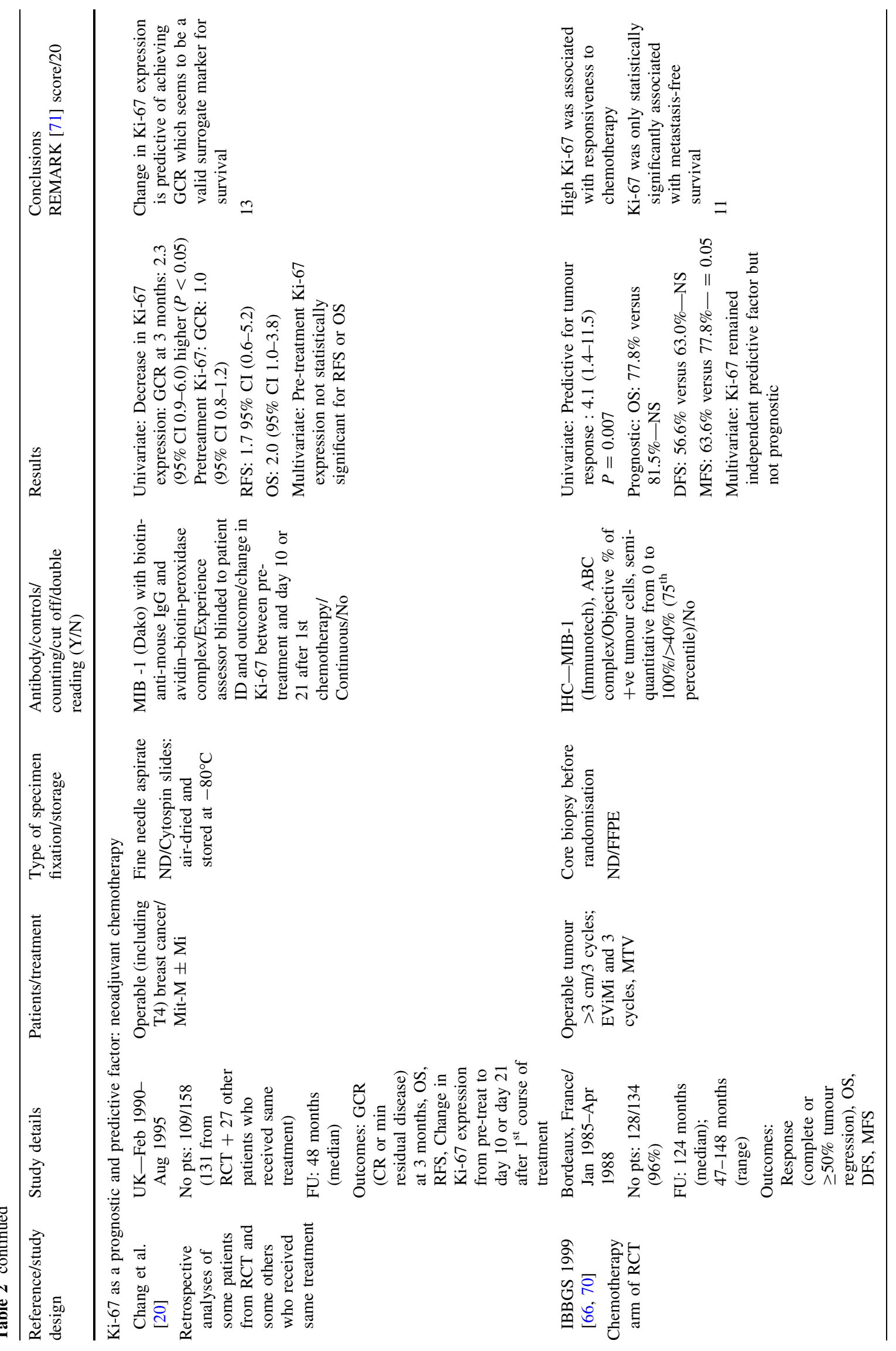




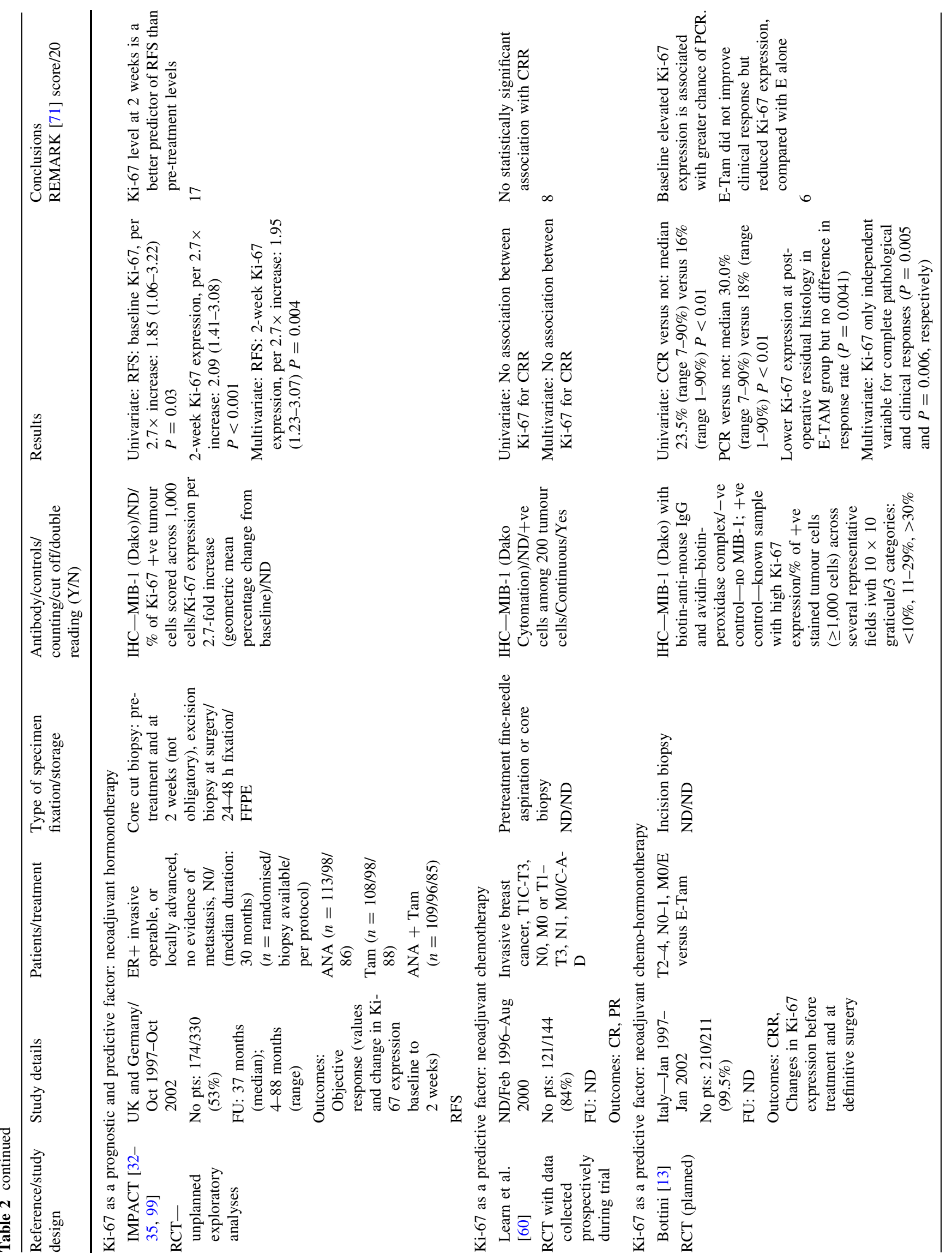




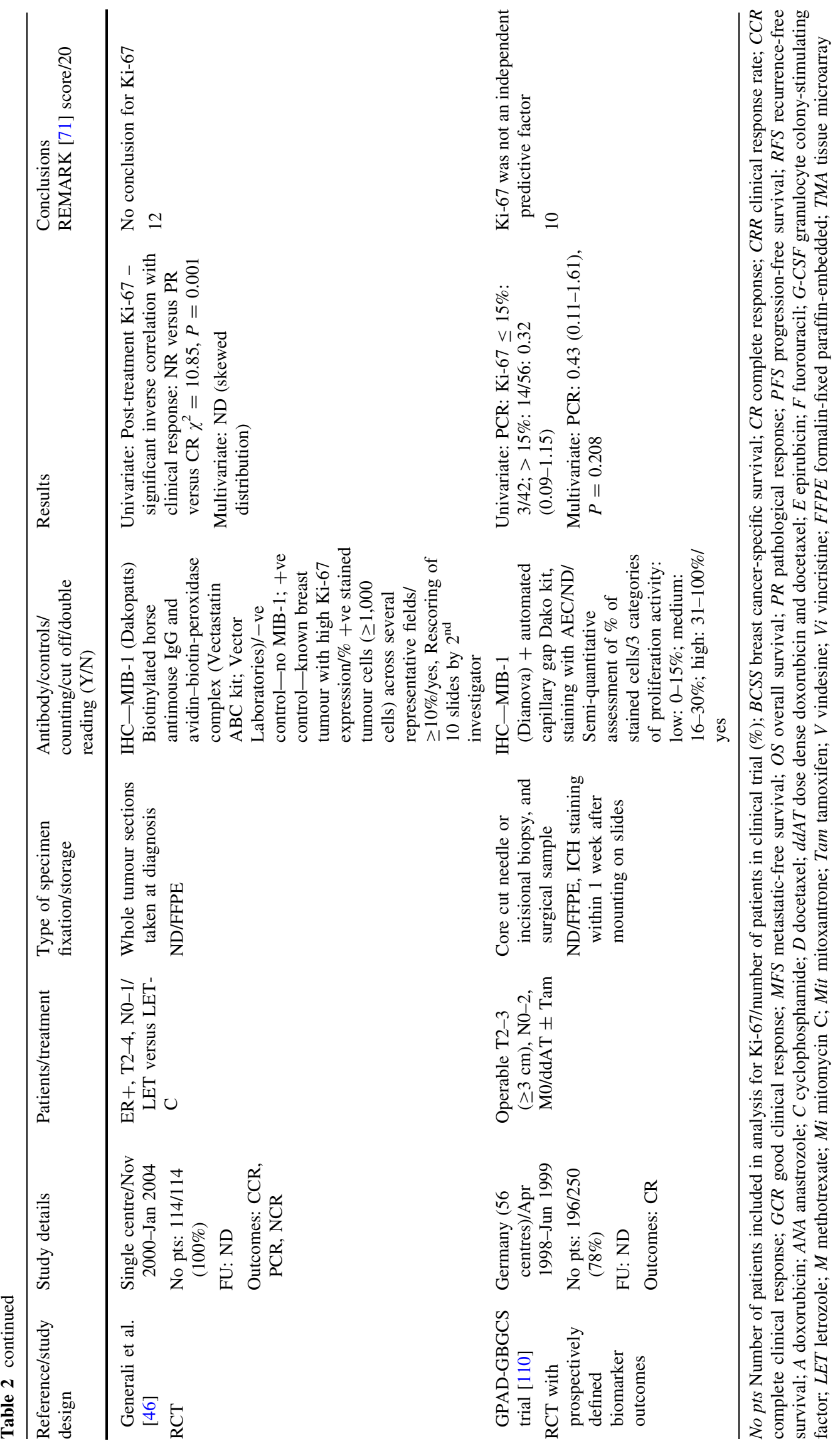




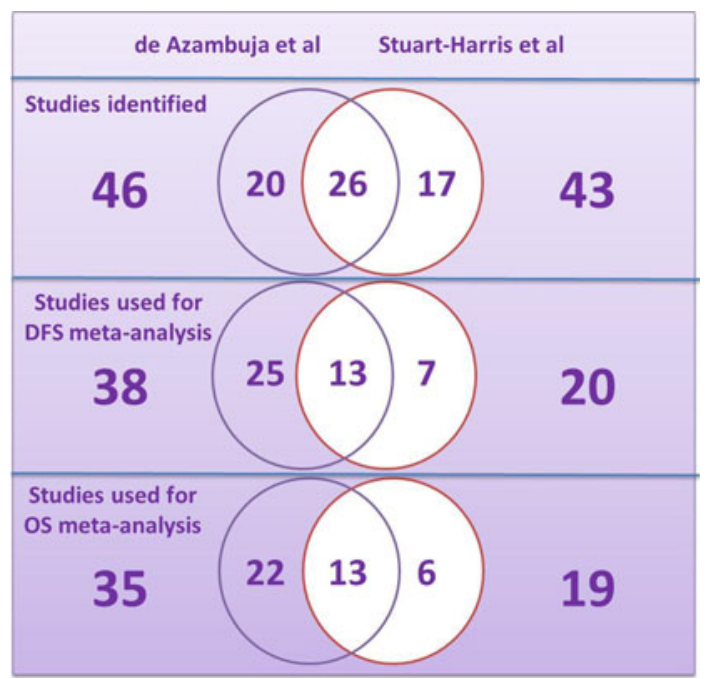

Fig. 2 Repartition of the studies included in the meta-analyses published by de Azambuja et al. [27] and Stuart-Harris et al. [100]. The numbers of studies common to both meta-analyses are shown in the overlapping circles and those unique to either one of the metaanalyses are shown in the non-overlapping parts of the circles. DFS Disease-free survival; $O S$ overall survival

The results from the studies using samples from patients included in RCTs do not provide sufficient proof to conclude that $\mathrm{Ki}-67$ is a predictive factor for short-term or long-term response to chemotherapy, since the study designs were not suitable for answering this question. The LOE is therefore II-B and a higher LOE will only be possible if suitably designed prospective studies are conducted. Nevertheless, an association between high Ki-67 expression at baseline and immediate response to hormonotherapy or chemotherapy in the neoadjuvant setting was reported in seven case series [14, 15, 73, 78, 82, 84, 90], two of them with pathological complete response (pCR) [73, 78]. The studies in the neoadjuvant chemotherapy setting analysed pCR as the endpoint. In contrast, the studies in the neoadjuvant hormonotherapy setting, used a clinical response endpoint. In breast cancer samples from women with incomplete pathological response after neoadjuvant therapy, the $\mathrm{Ki}-67$ expression in the residual tumour was reported to be prognostic, irrespective of the original pre-treatment value $[40,59,102]$.

Prognostic variables are needed in clinical practice. Histological grade can clearly distinguish between low and high risks tumours (grade 1 vs. grade 3 ) in terms of outcomes. However, about $40-50 \%$ of breast cancers are classified as grade 2 with a less well-defined risk. The histological grading system is constructed from a parameter of differentiation (glandular formation), nuclear appearance and a clear proliferation parameter (mitotic count). This explains why grade and Ki-67 index are closely linked, and why the grade is not always integrated in the multivariated models used for assessing Ki-67. The fact that such a link exists does not mean that the parameters are redundant and the use of Ki-67 index in a grade 2 population could be particularly useful to sub-classify them [2]. Patients with ER+ tumours are systematically treated by hormonotherapy today in the absence of contra-indications. It is possible that a $\mathrm{Ki}-67$ assessment prior to deciding to propose additional adjuvant chemotherapy might be useful for a subset of ER+ patients with grade 2 tumours.

The choice of the cut-point has a major impact in practice, as it determines which patients are classified as 'high Ki-67', and therefore which have a poorer prognosis. These patients will generally receive more aggressive therapy. In the published studies reviewed, many different

Table 3 Comparison of the methods used in the meta-analyses published by de Azambuja et al. [27] and Stuart-Harris et al. [100]

\begin{tabular}{lll}
\hline & de Azambuja et al. [27] & Stuart-Harris et al. [100] \\
\hline $\begin{array}{l}\text { Publication year } \\
\begin{array}{l}\text { Period for literature } \\
\text { search }\end{array}\end{array}$ & $\begin{array}{l}2007 \\
\text { Up to May 2006 }\end{array}$ & $\begin{array}{l}2008 \\
\text { January 1995-September 2004 }\end{array}$ \\
$\begin{array}{l}\text { Exclusion criteria } \\
\text { Non-English publications }\end{array}$ & $\begin{array}{l}\text { Non-English publications } \\
\text { Studies with fewer than 100 patients } \\
43\end{array}$ \\
$\begin{array}{l}\text { Number of studies } \\
\text { identified }\end{array}$ & 46 & 20 \\
$\begin{array}{l}\text { Included in DFS } \\
\text { analysis }\end{array}$ & 38 & 19 \\
$\begin{array}{l}\text { Included in OS } \\
\text { analysis }\end{array}$ & 35 & Studies that provided an HR or data that \\
$\begin{array}{l}\text { Inclusion of studies } \\
\text { for meta-analyses }\end{array}$ & enabled the HR to calculated & $\begin{array}{c}\text { Only studies that provided an HR for either OS or DFS, in either univariate } \\
\text { or multivariate analysis; if no 95\% CI it was calculated }\end{array}$ \\
\hline
\end{tabular}

${ }^{a}$ See Fig. 2 for details of common and unique studies 
Table 4 Description of meta-analyses of studies of Ki-67 as a prognostic factor

\begin{tabular}{|c|c|c|c|}
\hline Reference & $\begin{array}{l}\text { Factors studied } \\
\text { Search strategy described } \\
\text { (yes/no) } \\
\text { Date range number of studies } \\
\text { identified (number of } \\
\text { patients) }\end{array}$ & $\begin{array}{l}\text { Outcome } \\
\text { Analysis: number } \\
\text { of studies (number of patients) }\end{array}$ & Results \\
\hline \multirow{12}{*}{$\begin{array}{l}\text { de Azambuja } \\
\text { et al. [27] }\end{array}$} & \multirow{12}{*}{$\begin{array}{l}\text { Ki-67 } \\
\text { Yes } \\
\text { Up to May } 2006 \\
\text { Identified: } 68 \text { studies (? } \\
\text { patients) }\end{array}$} & \multicolumn{2}{|l|}{ DFS } \\
\hline & & \multirow[t]{3}{*}{ All studies: 38 studies (10,954 patients) } & Fixed effect HR: 1.88 (1.75-2.02) \\
\hline & & & $P$-heterogeneity $=0.01$ \\
\hline & & & Random effect HR: 1.93 (1.74-2.14) \\
\hline & & Node negative: 15 studies (3,370 patients) & $\begin{array}{l}\text { Fixed effect HR: } 2.20(1.88-2.58) \\
P \text {-heterogeneity }=0.03 \\
\text { Random effect HR: } 2.31(1.83-2.92)\end{array}$ \\
\hline & & Node positive: 8 studies (1,430 patients) & $\begin{array}{l}\text { Fixed effect HR: } 1.59(1.35-1.87) \\
P \text {-heterogeneity }=0.68\end{array}$ \\
\hline & & Node negative (untreated): 6 studies (736 patients) & $\begin{array}{l}\text { Fixed effect HR: } 2.72(1.97-3.75) \\
P \text {-heterogeneity }=0.89\end{array}$ \\
\hline & & \multicolumn{2}{|l|}{ OS } \\
\hline & & All studies: 35 studies ( 9,472 patients) & $\begin{array}{l}\text { Fixed effect HR: } 1.89(1.74-2.06) \\
P \text {-heterogeneity }<0.001 \\
\text { Random effect HR: } 1.95(1.70-2.24)\end{array}$ \\
\hline & & Node negative: 9 studies (1,996 patients) & $\begin{array}{l}\text { Fixed effect HR: } 2.19(1.76-2.72) \\
P \text {-heterogeneity }=0.001 \\
\text { Random effect HR: } 2.54(1.65-3.19)\end{array}$ \\
\hline & & Node positive: 4 studies ( 857 patients) & $\begin{array}{l}\text { Fixed effect HR: } 2.33(1.83-2.95) \\
P \text {-heterogeneity }=0.44\end{array}$ \\
\hline & & $\begin{array}{l}\text { Node negative/positive (untreated): } 2 \text { studies ( } 238 \\
\text { patients) }\end{array}$ & $\begin{array}{l}\text { Fixed effect HR: } 1.79(1.22-2.63) \\
P \text {-heterogeneity }=0.36\end{array}$ \\
\hline \multirow{8}{*}{$\begin{array}{l}\text { Stuart-Harris } \\
\text { et al. [100] }\end{array}$} & Ki-67, mitotic index, PCNA, & \multicolumn{2}{|l|}{ DFS } \\
\hline & & \multirow[t]{3}{*}{ Univariate analysis: 15 studies (?) } & Unadjusted HR: $2.18(1.92-2.47) P<10^{-5}$ \\
\hline & & & $P$-heterogeneity $=0.21$ \\
\hline & & & $P$-publication bias $=0.002$ \\
\hline & \multirow[t]{4}{*}{$\begin{array}{l}\text { Identified: } 43 \text { studies }(15,790 \\
\text { patients) }\end{array}$} & Multivariate analysis: 14 studies (?) & $\begin{array}{l}\text { Adjusted HR (4 studies added): } 2.05(1.80-2.33) \\
\text { Unadjusted HR: } 1.84(1.62-2.10) P<10^{-5} \\
P \text {-heterogeneity }=0.93 \\
P \text {-publication bias }=0.019 \\
\text { Adjusted HR ( } 5 \text { studies added): } 1.76(1.56-1.98)\end{array}$ \\
\hline & & \multicolumn{2}{|l|}{ OS } \\
\hline & & Univariate analysis: 12 studies (?) & $\begin{array}{l}\text { Unadjusted HR: } 2.09(1.74-2.52) P<10^{-5} \\
P \text {-heterogeneity }=0.037 \\
P \text {-publication bias }=0.074 \\
\text { Adjusted HR (4 studies added): } 1.88(1.55-2.27)\end{array}$ \\
\hline & & Multivariate analysis: 13 studies (?) & $\begin{array}{l}\text { Unadjusted HR: } 1.73(1.37-2.17) P<10^{-5} \\
P \text {-heterogeneity }<10^{-5} \\
P \text {-publication bias }=0.001 \\
\text { Adjusted HR (5 studies added): } 1.42(1.14-1.77)\end{array}$ \\
\hline
\end{tabular}

PCNA Proliferating cell nuclear antigen; $L I$ labelling index

ways to select a cut-point were used, defining two or three subgroups. These include an arbitrary choice based either on the different cut-points proposed in the literature or the use of the "significant" mean value from an 'in house' series. In our review of studies using samples from RTCs, most arbitrary cut-points for adjuvant treatment choice were distributed between 5 and $34 \%$ with 10 or $20 \%$ being the most frequently used values (Table 2). 
Table 5 Summary of assessment of various markers as prognostic factors for DFS in women with breast cancer

\begin{tabular}{lll}
\hline Reference $^{\mathrm{a}}$ & Marker & HR (95\% CI) \\
\hline Stuart-Harris et al. [100] & Ki-67 & $1.76(1.56-1.98)$ \\
Rakha et al. [94] & SBR grade (3 vs. 1) & $1.6(1.3-2.0)$ \\
Look et al. [64] & uPA/PAI-1 (pN0) & $2.37(1.78-3.16)$ \\
Rakha et al. [94] & Node status & $1.5(1.4-1.7)$ \\
Wirapati et al. [113] & ER (neg. vs. high) & $2.2(1.6-3.0)$ \\
Blows et al. [10] & HER2 & $1.55(1.23-1.96)$
\end{tabular}

SBR Scarf-Bloom-Richardson histological grading system

${ }^{a}$ Not all patients received systemic adjuvant treatment

The use of data-derived 'optimal' cut-points can result in serious bias due to different patient populations in each series. It should be stressed that transforming continuous variables, such as the Ki-67 index, into two categories can lead to a loss of power of the biomarker [88, 95, 108, 109]. In addition, this is unrealistic at the individual level, since it suggests that patients, who have tumours with Ki-67 levels close to the cut-point but on either side of the cutpoint, are very different, whereas in reality they are probably very similar. Technically it is not necessary for statistical analysis to have a binary variable, and it has been show that a model with continuous values provides more information [95]. In clinical practice, one way of expressing the results is to use two cut-point values which define a central 'grey' area between the low and high values. For patients whose Ki-67 level falls in this grey area, other factors could be considered in the decision to offer chemotherapy or not. This is the approach adopted by the St Gallen International Expert Consensus who recommended the use of Ki-67 to measure proliferation [47, 48, 95]; women with ER+ tumours and 'high' Ki-67 (i.e. $>30 \%$ ) should receive chemo-hormonotherapy, those with 'low' Ki-67 ( $\leq 15 \%)$ (luminal A tumours) should receive hormonotherapy alone and the 'intermediate' level (16-30\%) is not decisive for therapeutic decision.

$\mathrm{Ki}-67$ expression is detected by immunohistochemical techniques on histological slides. Molecular testing using RT-QPCR on fixed-paraffin embedded tissue samples is also feasible [28] but not used in practice. Both techniques give quantitative results but the qualitative aspect of tumour heterogeneity is only accessible on histology slides. Comparative studies are in progress but the results are not yet available. Moreover, both techniques, as for all biomarkers, need standardized pre-analytical conditions which require cooperation between radiologists, surgeons, and pathologists. Most laboratories use MIB-I or SP6 antibodies for immunohistochemistry that provide highly comparable results, although SP6 appears to be better suited for image analysis [116]. However, the methods of antigen retrieval from paraffin-embedded samples, the concentrations of antibodies, the time of incubation, as well as the amplification reagents vary and may significantly influence the final results $[114,116]$. We observed this variation in the studies analysed in this review (Table 2). Automatic immunostaining was reported to be used in only three of the published studies, despite the fact that most laboratories are nowadays equipped with such systems [88, 108, 109]. Also, the way samples are treated immediately after collection and the way they are stored may affect the final results, but generally only sparse information on this was provided in most of studies reported. In general, all studies reported using a negative control. However, there was no standardized positive control for staining calibration. Some studies used tonsil tissue, while others used known highly positive breast cancer tissue. The intensity of nuclear staining that was considered to be positive also varied; in some cases any staining was taken as positive, whereas in others positivity required 'marked' staining. Some studies reported using 'hot spots' (or areas of intense staining) for the assessment, whereas others used fields with different intensity of staining giving the result as a mean value. Significant variation in the number of fields examined, the number of tumour cells counted or estimated, the use of a graticule for counting or the use of automated counting systems was also seen. Some studies reported a double reading of all slides, or of a certain percentage of slides.

Due to limits in histological quantitative analysis and tumour heterogeneity, leading to inter/intra-observer variations on grade scoring, some grade 2 tumours are misclassified as grade 1 , and also some grade 1 tumours are mis-classified as grade 2. The assessment of Ki-67 levels in these borderline cases provides additional information to clinicians. Similar overlap exists between grade 2 and grade 3 tumours, but without a significant impact on therapeutic decision. In view of the inaccuracies expected in the Ki-67 index values, partly due to the heterogeneity of the techniques as discussed above, and partly due to tumour heterogeneity, it may be useful to generalize automated quantitative image analysis, to report both 'hot spots' and mean Ki-67 values, and to expand the 16-30\% intermediate level of St Gallen to 11-30\% [47]. This wider intermediate level would ensure a better identification of tumours with low and high levels of Ki-67. The risk of making an error when assessing a Ki-67 score $<10$ or $>30 \%$ will be low in routine practice, but is to be expected for the intermediate level between 11 and 30\%, requiring, therefore, double assessment or automated image analysis.

Reporting key details are essential to assess the reliability of the study results. Initiatives such as the CONSORT guidelines have been shown to improve the quality of reporting for RCTs [74, 75]. In a similar way, the REMARK guidelines were developed to improve reporting 
of prognostic studies and their results [71]. Mallett et al. [68] reported in 2010 the results from an analysis of reports of prognostic tumour marker studies published in 2006 and 2007 using the REMARK score. The aim of their study was to assess if the publication of the guidelines had had an immediate impact on the quality of the reported studies. Although most of the studies reported the number of patients in the analyses (98\%), only just over half reported the number of eligible patients $(56 \%)$ and excluded patients $(54 \%)$. Only $36 \%$ of the reports clearly defined the outcomes analysed. The authors concluded that although good reporting is essential for the interpretation and clinical application of prognostic studies, the standards of reporting in 2006 and 2007 were poor. They called for a wider use of the REMARK guidelines to help improve reporting and enhance prognostic research. The results of our review show that articles published prior to the publication of REMARK in 2005 had a lower range of REMARK scores $(n=9 ; 6-13)$ than those published after $(n=9 ; 10-18)$ which suggests that the quality of reporting has improved.

\section{Conclusions}

The results from this review show that Ki-67 provides useful information for therapeutic decisions in breast cancer patients. It is an independent prognostic factor for DFS and the greatest benefits from Ki-67 assessment could be observed in patients with ER+ breast cancers. It is not predictive for chemotherapy, but high KI-67 was found to be associated with immediate $\mathrm{pCR}$ in the neoadjuvant setting.

In view of these results, international guidelines should help to standardize the pre-analytical phase, the staining techniques and the counting methods. We also need to standardize the cut-point determination to ensure that Ki67 results can be used with confidence in clinical practice.

Acknowledgments The project was funded by The French Senology and Breast Pathology Society ("Société Française de Sénologie et de Pathologie Mammaire"; SFSPM). The working group comprised 10 oncologists, 8 pathologists, 4 medical biologists, 1 gynaecologist, 1 methodologist and 1 oncologist/methodologist. Jean-Pierre Bellocq was the working group coordinator.

Ethical standards This project was performed in compliance with the relevant ethical standards in France.

Conflict of interest The authors declare that they have no conflicts of interest to declare.

\section{Appendix 1}

See Table 6.
Table 6 Keywords for PubMed search

Keywords for disease and treatment

("Breast neoplasms" [all fields]) OR cancer* or carcinoma* or adenocarcinoma* or tumor* or tumour*

Chemotherapy, adjuvant

Neoadjuvant therapy/methods*

Breast cancer proliferation

Breast cancer grade

Breast adjuvant treatment

Chemotherapy response marker

Breast chemotherapy response marker

Keywords for Ki-67

Ki-67 proliferation

Ki-67 breast cancer

Ki-67 immunohistochemistry

Ki-67 labelling index

MIB-1 antibody [substance name]

Mitosis/genetics

Predictive value of tests [mesh]

"Biological markers/analysis" [mesh]

Tumour markers, biological/analysis

Immunohistochemistry

Ki-67 tissue micro array

Ki-67 core biopsy

Proliferation index

Breast proliferation index

Ki-67

Keywords for type of study

Randomized controlled trial

Controlled clinical trial

Clinical trial

Meta-analysis

Practice guideline

Prognosis

Multivariate analysis

Evidence-based medicine

\section{Appendix 2}

See Table 7.

Table 7 Data items extracted for each study

Data item

General information about study and samples:

Study name (and bibliographic reference)

Study design

Treatment

Country and period

Outcomes 
Table 7 continued

\begin{tabular}{l}
\hline Data item \\
\hline Number of patients in trial/number of samples in study (\%) \\
Duration of follow-up \\
Tumour characteristics \\
Ki-67 as prognostic factor, predictive factor or both \\
Information about the treatment received \\
Neoadjuvant (details) \\
Adjuvant (details) \\
Both neoadjuvant and adjuvant (details) \\
Information about specimen treatment \\
Type of tissue \\
Pre-analytical conditions (fixation delay, fixation time) (yes/no) \\
Methods of preservation and storage \\
Information about Ki-67 assay \\
Materials and methods for Ki-67 assay \\
Quality control procedures \\
Scoring system used \\
Cut-off value \\
Double reading (yes/no) \\
Results \\
Univariate analyses \\
Multivariate analyses \\
Conclusion \\
SEMARK score
\end{tabular}

\section{References}

1. Aleskandarany MA, Green AR, Rakha EA, Mohammed RA, Elsheikh SE, Powe DG, Paish EC, Macmillan RD, Chan S, Ahmed SI, Ellis IO (2010) Growth fraction as a predictor of response to chemotherapy in node-negative breast cancer. Int $\mathbf{J}$ Cancer 126:1176-1761. doi:10.1002/ijc.24860

2. Aleskandarany MA, Rakha EA, Macmillan RD, Powe DG, Ellis IO, Green AR (2010) MIB1/Ki-67 labelling index can classify grade 2 breast cancer into two clinically distinct subgroups. Breast Cancer Res Treat 127:591-599. doi:10.1007/s10549-0101028-3

3. Andreetta C, Puppin C, Minisini A, Valent F, Pegolo E, Damante G, Di Loreto C, Pizzolitto S, Pandolfi M, Fasola G, Piga A, Puglisi F (2009) Thymidine phosphorylase expression and benefit from capecitabine in patients with advanced breast cancer. Ann Oncol 20:265-271. doi:10.1093/annonc/mdn592

4. Assersohn L, Salter J, Powles TJ, A'Hern R, Makris A, Gregory RK, Chang J, Dowsett M (2003) Studies of the potential utility of Ki67 as a predictive molecular marker of clinical response in primary breast cancer. Breast Cancer Res Treat 82:113-123

5. Bartlett JMS, Munro A, Cameron Da, Thomas J, Prescott R, Twelves CJ (2008) Type 1 receptor tyrosine kinase profiles identify patients with enhanced benefit from anthracyclines in the BR9601 Adjuvant Breast Cancer Chemotherapy Trial. J Clin Oncol 26:5027-5035

6. Bartlett JM, Munro AF, Dunn Ja, McConkey C, Jordan S, Twelves CJ, Cameron Da, Thomas J, Campbell FM, Rea DW
(2010) Predictive markers of anthracycline benefit: a prospectively planned analysis of the UK National Epirubicin Adjuvant Trial (NEAT/BR9601). Lancet Oncol 11:266-274

7. Beck T, Weller EE, Weikel W, Brumm C, Wilkens C, Knapstein PG (1995) Usefulness of immunohistochemical staining for p53 in the prognosis of breast carcinomas: correlations with established prognosis parameters and with the proliferation marker, MIB-1. Gynecol Oncol 57:96-104

8. Bellera CA, MacGrogan G, Debled M, de Lara C, Brouste V, Mathoulin-Pélissier S (2010) Variables with time-varying effects and the Cox model: some statistical concepts illustrated with a prognostic factor study in breast cancer. BMC Med Res Methodol 10:20. doi:10.1186/1471-2288-10-20

9. Billgren AM, Tani E, Liedberg A, Skoog L, Rutqvist LE (2002) Prognostic significance of tumor cell proliferation analyzed in fine needle aspirates from primary breast cancer. Breast Cancer Res Treat 71:161-170

10. Blows FM, Driver KE, Schmidt MK, Broeks A, van Leeuwen FE, Wesseling J, Cheang MC, Gelmon K, Nielsen TO, Blomqvist C, Heikkilä P, Heikkinen T, Nevanlinna H, Akslen La, Bégin LR, Foulkes WD, Couch FJ, Wang X, Cafourek V, Olson JE, Baglietto L, Giles GG, Severi G, McLean Ca, Southey MC, Rakha E, Green AR, Ellis IO, Sherman ME, Lissowska J, Anderson WF, Cox A, Cross SS, Reed MWR, Provenzano E, Dawson S-J, Dunning AM, Humphreys M, Easton DF, García-Closas M, Caldas C, Pharoah PD, Huntsman D (2010) Subtyping of breast cancer by immunohistochemistry to investigate a relationship between subtype and short and long term survival: a collaborative analysis of data for 10,159 cases from 12 studies. PLoS Med 7:e1000279

11. Bonnefoi H, Diebold-Berger S, Therasse P, Hamilton A, van de Vijver M, MacGrogan G, Shepherd L, Amaral N, Duval C, Drijkoningen R, Larsimont D, Piccart M (2003) Locally advanced/inflammatory breast cancers treated with intensive epirubicin-based neoadjuvant chemotherapy: are there molecular markers in the primary tumour that predict for 5-year clinical outcome? Ann Oncol 14:406-413. doi:10.1093/annonc/mdg108

12. Bonnefoi H, Underhill C, Iggo R, Cameron D (2009) Predictive signatures for chemotherapy sensitivity in breast cancer: are they ready for use in the clinic? Eur J Cancer 45:1733-1743. doi:10.1016/j.ejca.2009.04.036

13. Bottini A (2005) Cytotoxic and antiproliferative activity of the single agent epirubicin versus epirubicin plus tamoxifen as primary chemotherapy in human breast cancer: a single-institution phase III trial. Endocr Relat Cancer 12:383-392. doi: 10.1677/erc.1.00945

14. Bottini A, Berruti A, Bersiga A, Brizzi MP, Brunelli A, Gorzegno G, DiMarco B, Aguggini S, Bolsi G, Cirillo F, Filippini L, Betri E, Bertoli G, Alquati P, Dogliotti L (2000) P53 but not $\mathrm{Bcl}-2$ immunostaining is predictive of poor clinical complete response to primary chemotherapy in breast cancer patients. Clin Cancer Res 6:2751-2758

15. Bottini A, Berruti A, Bersiga A, Brizzi MP, Bruzzi P, Aguggini S, Brunelli A, Bolsi G, Allevi G, Generali D, Betri E, Bertoli G, Alquati P, Dogliotti L (2001) Relationship between tumour shrinkage and reduction in Ki67 expression after primary chemotherapy in human breast cancer. Br J Cancer 85:1106-1112

16. Bozzetti C, Musolino A, Camisa R, Bisagni G, Flora M, Bassano C, Martella E, Lagrasta C, Nizzoli R, Personeni N, Leonardi F, Cocconi G, Ardizzoni A (2006) Evaluation of HER-2/ neu amplification and other biological markers as predictors of response to neoadjuvant anthracycline-based chemotherapy in primary breast cancer: the role of anthracycline dose intensity. Am J Clin Oncol 29:171-177

17. Brown RW, Allred C, Clark GM, Osborne K, Hilsenbeck SG (1996) Prognostic value of Ki-67 compared to S-phase fraction in axillary breast cancer. Clin Cancer Res 2:585-592 
18. Burcombe RJ, Makris A, Richman PI, Daley FM, Noble S, Pittam M, Wright D, Allen SA, Dove J, Wilson GD (2005) Evaluation of ER, PgR, HER-2 and Ki-67 as predictors of response to neoadjuvant anthracycline chemotherapy for operable breast cancer. Br J Cancer 92:147-155. doi:10.1038/sj.bjc. 6602256

19. Capodanno A, Camerini A, Orlandini C, Baldini E, Resta ML, Bevilacqua G, Collecchi P (2009) Dysregulated PI3K/Akt/ PTEN pathway is a marker of a short disease-free survival in node-negative breast carcinoma. Hum Pathol 40:1408-1417

20. Chang J, Powles TJ, Allred DC, Ashley SE, Clark GM, Makris A, Assersohn L, Gregory RK, Osborne CK, Dowsett M (1999) Biologic markers as predictors of clinical outcome from systemic therapy for primary operable breast cancer. J Clin Oncol 17:3058-3063

21. Chang J, Powles TJ, Allred DC, Ashley SE, Makris A, Gregory RK, Osborne CK, Dowsett M (2000) Prediction of clinical outcome from primary tamoxifen by expression of biologic markers in breast cancer patients. Clin Cancer Res 6:616-621

22. Cheang MCU, Chia SK, Voduc D, Gao D, Leung S, Snider J, Watson M, Davies S, Bernard PS, Parker JS, Perou CM, Ellis MJ, Nielsen TO (2009) Ki67 index, HER2 status, and prognosis of patients with luminal B breast cancer. J Natl Cancer Inst 101:736-750

23. Colleoni M, Viale G, Zahrieh D, Bottiglieri L, Gelber RD, Veronesi P, Balduzzi A, Torrisi R, Luini A, Intra M, Dellapasqua S, Cardillo A, Ghisini R, Peruzzotti G, Goldhirsch A (2008) Expression of ER, PgR, HER1, HER2, and response: a study of preoperative chemotherapy. Ann Oncol 19:465-472

24. Colozza M, Azambuja E, Cardoso F, Sotiriou C, Larsimont D, Piccart MJ (2005) Proliferative markers as prognostic and predictive tools in early breast cancer: where are we now? Ann Oncol 16:1723-1739

25. Cuzick J, Dowsett M, Wale C, Salter J, Quinn E, Zabaglo L, Howell A, Buzdar A, Forbes J (2009) Prognostic value of a combined ER, PgR, Ki67, HER2 immunohistochemical (IHC4) score and comparison with the GHI recurrence score-results from TransATAC. Cancer Res 69:74

26. Dai $\mathrm{H}$ (2005) A cell proliferation signature is a marker of extremely poor outcome in a subpopulation of breast cancer patients. Cancer Res 65:4059-4066. doi:10.1158/0008-5472. can-04-3953

27. de Azambuja E, Cardoso F, de Castro G, Colozza M, Mano MS, Durbecq V, Sotiriou C, Larsimont D, Piccart-Gebhart MJ, Paesmans M (2007) Ki-67 as prognostic marker in early breast cancer: a meta-analysis of published studies involving 12,155 patients. Br J Cancer 96:1504-1513

28. de Cremoux P (2004) Inter-laboratory quality control for hormone-dependent gene expression in human breast tumors using real-time reverse transcription-polymerase chain reaction. Endocr Relat Cancer 11:489-495. doi:10.1677/erc.1.00808

29. Decensi A, Guerrieri-Gonzaga A, Gandini S, Serrano D, Cazzaniga M, Mora S, Johansson H, Lien Ea, Pruneri G, Viale G, Bonanni B (2010) Prognostic significance of Ki-67 labeling index after short-term presurgical tamoxifen in women with ERpositive breast cancer. Ann Oncol 22:582-587

30. Dettmar P, Harbeck N, Thomssen C, Pache L, Ziffer P, Fizi K, Janicke F, Nathrath W, Schmitt M, Graeff H, Hoflerl H (1997) Prognostic impact of proliferation-associated factors MIBI (Ki67) and S-phase in node-negative breast cancer. $\mathrm{Br} \mathrm{J}$ Cancer 75:1525-1533

31. Diamandis EP (2010) Cancer biomarkers: can we turn recent failures into success? J Natl Cancer Inst 102:1462-1467. doi: 10.1093/jnci/djq306

32. Dowsett M (2006) Proliferation and apoptosis as markers of benefit in neoadjuvant endocrine therapy of breast cancer. Clin
Cancer Res 12:1024s-1030s. doi:10.1158/1078-0432. ccr-05-2127

33. Dowsett M, Smith IE, Ebbs SR, Dixon JM, Skene A, Griffith C, Boeddinghaus I, Salter J, Detre S, Hills M, Ashley S, Francis S, Walsh G (2005) Short-term changes in Ki-67 during neoadjuvant treatment of primary breast cancer with anastrozole or tamoxifen alone or combined correlate with recurrence-free survival. Clin Cancer Res 11:951s-958s

34. Dowsett M, Smith IE, Ebbs SR, Dixon JM, Skene A, A'Hern R, Salter J, Detre S, Hills M, Walsh G (2007) Prognostic value of Ki67 expression after short-term presurgical endocrine therapy for primary breast cancer. J Natl Cancer Inst 99:167-170. doi: 10.1093/jnci/djk020

35. Dowsett M, Procter M, McCaskill-Stevens W, de Azambuja E, Dafni U, Rueschoff J, Jordan B, Dolci S, Abramovitz M, Stoss O, Viale G, Gelber RD, Piccart-Gebhart M, Leyland-Jones B (2009) Disease-free survival according to degree of HER2 amplification for patients treated with adjuvant chemotherapy with or without 1 year of trastuzumab: the HERA trial. J Clin Oncol 27:2962-2969

36. Dumontet C, Krajewska M, Treilleux I, Mackey JR, Martin M, Rupin M, Lafanechere L, Reed JC (2010) BCIRG 001 molecular analysis: prognostic factors in node-positive breast cancer patients receiving adjuvant chemotherapy. Clin Cancer Res 16:3988-3997. doi:10.1158/1078-0432.ccr-10-0079

37. Earl HM, Hiller L, Dunn J, Bathers S, Harvey P, Stanley A, Grieve RJ, Agrawal RK, Fernando IN, Brunt AM, McAdam K, O'Reilly S, Rea DW, Spooner D, Poole CJ (2008) NEAT: National Epirubicin Adjuvant Trial-toxicity, delivered dose intensity and quality of life. Br J Cancer 99:1226-1231

38. Early Breast Cancer Trialists Collaborative Group (2005) Effects of chemotherapy and hormonal therapy for early breast cancer on recurrence and 15-year survival: an overview of the randomised trials. Lancet 365:1687-1717

39. Ellis MJ, Ma C (2007) Letrozole in the neoadjuvant setting: the P024 trial. Breast Cancer Res Treat 105(Suppl):33-43

40. Ellis MJ, Miller WR, Tao Y, Evans DB, Chaudri Ross HA, Miki Y, Suzuki T, Sasano H (2008) Aromatase expression and outcomes in the P024 neoadjuvant endocrine therapy trial. Breast Cancer Res Treat 116:371-378. doi:10.1007/s10549-008-0161-8

41. Ellis MJ, Tao Y, Luo J, A'Hern R, Evans DB, Bhatnagar AS, Chaudri Ross HA, von Kameke A, Miller WR, Smith I, Eiermann W, Dowsett M (2008) Outcome prediction for estrogen receptor-positive breast cancer based on postneoadjuvant endocrine therapy tumor characteristics. J Natl Cancer Inst 100:1380-1388

42. Erdem O, Dursun A, Coşkun U, Günel N (2005) The prognostic value of p53 and c-erbB-2 expression, proliferative activity and angiogenesis in node-negative breast carcinoma. Tumori 91:46-52

43. Estévez LG, Cuevas JM, Antón A, Florián J, López-Vega JM, Velasco A, Lobo F, Herrero A, Fortes J (2003) Weekly docetaxel as neoadjuvant chemotherapy for stage II and III breast cancer: efficacy and correlation with biological markers in a phase II, multicenter study. Clin Cancer Res 9:686-692

44. Falck A-K, Fernö M, Bendahl P-O, Rydén L (2010) Does analysis of biomarkers in tumor cells in lymph node metastases give additional prognostic information in primary breast cancer? World J Surg 34:1434-1441. doi:10.1007/s00268-010-0499-z

45. Gasparini G, Bevilacqua P, Pozza F, Meli S, Boracchi P, Marubini E, Sainsbury JR (1992) Value of epidermal growth factor receptor status compared with growth fraction and other factors for prognosis in early breast cancer. $\mathrm{Br} \mathrm{J}$ Cancer 66:970-976

46. Generali D, Buffa FM, Berruti A, Brizzi MP, Campo L, Bonardi S, Bersiga A, Allevi G, Milani M, Aguggini S, Papotti M, 
Dogliotti L, Bottini A, Harris AL, Fox SB (2009) Phosphorylated $\mathrm{ER} \alpha$, HIF- $1 \alpha$, and MAPK signaling as predictors of primary endocrine treatment response and resistance in patients with breast cancer. J Clin Oncol 27:227-234. doi:10.1200/jco. 2007.13.7083

47. Goldhirsch A, Ingle JN, Gelber RD, Coates AS, Thurlimann B, Senn HJ (2009) Thresholds for therapies: highlights of the St Gallen International Expert Consensus on the Primary Therapy of Early Breast Cancer 2009. Ann Oncol 20:1319-1329. doi: 10.1093/annonc/mdp322

48. Goldhirsch A, Wood WC, Coates AS, Gelber RD, Thurlimann B, Senn HJ (2011) Strategies for subtypes-dealing with the diversity of breast cancer: highlights of the St Gallen International Expert Consensus on the Primary Therapy of Early Breast Cancer 2011. Ann Oncol 22:1736-1747. doi:10.1093/annonc/ mdr304

49. Goodson WH, Moore DH, Ljung BM, Chew K, Mayall B, Smith HS, Waldman FM (2000) The prognostic value of proliferation indices: a study with in vivo bromodeoxyuridine and $\mathrm{Ki}-67$. Breast Cancer Res Treat 59:113-123

50. Harbeck N, Salem M, Nitz U, Gluz O, Liedtke C (2010) Personalized treatment of early-stage breast cancer: present concepts and future directions. Cancer Treat Rev 36:584-594

51. Harris L, Fritsche H, Mennel R, Norton L, Ravdin P, Taube S, Somerfield MR, Hayes DF, Bast RC (2007) American Society of Clinical Oncology 2007 update of recommendations for the use of tumor markers in breast cancer. J Clin Oncol 25:5287-5312

52. Hayes DF, Bast RC, Desch CE, Fritsche H, Kemeny NE, Jessup JM, Locker GY, Macdonald JS, Mennel RG, Norton L, Ravdin P, Taube S, Winn RJ (1996) Tumor marker utility grading system: a framework to evaluate clinical utility of tumor markers. J Natl Cancer Inst 88:1456-1466

53. Henry NL, Hayes DF (2006) Uses and abuses of tumor markers in the diagnosis, monitoring, and treatment of primary and metastatic breast cancer. Oncologist 11:541-552

54. Hlupić L, Jakić-Razumović J, Bozikov J, Corić M, Belev B, Vrbanec D (2004) Prognostic value of different factors in breast carcinoma. Tumori 90:112-119

55. Jacquemier J, Charafe-Jauffret E, Monville F, Esterni B, Extra J, Houvenaeghel G, Xerri L, Bertucci F, Birnbaum D (2009) Association of GATA3, P53, Ki67 status and vascular peritumoral invasion are strongly prognostic in luminal breast cancer. Breast Cancer Res 11:R23. doi:10.1186/bcr2249

56. Jansen RL, Hupperets PS, Arends JW, Joosten-Achjanie SR, Volovics A, Schouten HC, Hillen HF (1998) MIB-1 labelling index is an independent prognostic marker in primary breast cancer. Br J Cancer 78:460-465

57. Joensuu H, Isola J, Lundin M, Salminen T, Holli K, Kataja V, Turpeenniemi-Hujanen T, Smitten KV, Lundin J (2003) Amplification of erbB2 and erbB2 expression are superior to estrogen receptor status as risk factors for distant recurrence in pT1N0M0 breast cancer: a nationwide population-based study. Clin Cancer Res 9:923-930

58. Jonat W, Arnold N (2011) Is the Ki-67 labelling index ready for clinical use? Ann Oncol 22:500-502. doi:10.1093/annonc/ mdq732

59. Jones RL, Salter J, A'Hern R, Nerurkar A, Parton M, Reis-Filho JS, Smith IE, Dowsett M (2010) Relationship between oestrogen receptor status and proliferation in predicting response and longterm outcome to neoadjuvant chemotherapy for breast cancer. Breast Cancer Res Treat 119:315-323

60. Learn PA, Yeh IT, McNutt M, Chisholm GB, Pollock BH, Rousseau DL, Sharkey FE, Cruz AB, Kahlenberg MS (2005) HER-2/neu expression as a predictor of response to neoadjuvant docetaxel in patients with operable breast carcinoma. Cancer 103:2252-2260. doi:10.1002/cncr.21037
61. Lindboe CF, Torp SH (2002) Comparison of Ki-67 equivalent antibodies. J Clin Oncol 55:467-471

62. Liu S, Edgerton SM, Moore DH, Thor AD (2001) Measures of cell turnover (proliferation and apoptosis) and their association with survival in breast cancer. Clin Cancer Res 7:1716-1723

63. Lockwood CA, Ricciardelli C, Raymond WA, Seshadri R, McCaul K, Horsfall DJ (1999) A simple index using video image analysis to predict disease outcome in primary breast cancer. Int J Cancer 84:203-208

64. Look MP, van Putten WLJ, Duffy MJ, Harbeck N, Christensen IJ, Thomssen C, Kates R, Spyratos F, Fernö M, Eppenberger-Castori S, Sweep CGJF, Ulm K, Peyrat J-P, Martin P-M, Magdelenat H, Brünner N, Duggan C, Lisboa BW, Bendahl P-O, Quillien V, Daver A, Ricolleau G, Meijer-van Gelder M, Manders P, Fiets WE, Blankenstein Ma, Broët P, Romain S, Daxenbichler G, Windbichler G, Cufer T, Borstnar S, Kueng W, Beex LVAM, Klijn JGM, O'Higgins N, Eppenberger U, Jänicke F, Schmitt M, Foekens JA (2002) Pooled analysis of prognostic impact of urokinase-type plasminogen activator and its inhibitor PAI-1 in 8377 breast cancer patients. J Natl Cancer Inst 94:116-128

65. Lopez F, Belloc F, Lacombe F, Dumain P, Reiffers J, Bernard P, Boisseau MR (1991) Modalities of synthesis of Ki67 antigen during the stimulation of lymphocytes. Cytometry 12:42-49

66. MacGrogan G, Mauriac L, Durand M, Bonichon F, Trojani M, Mascarell ID, Coindre JM (1996) Primary chemotherapy in breast invasive carcinoma: predictive value of the immunohistochemical detection of hormonal receptors, p53, c-erbB-2, MiB1, pS2 and GST2. Br J Cancer 74:1458-1465

67. Makris A, Powles TJ, Osborne CK, Trott PA, Fernando IN, Ashley SE, Ormerod MG, Titley JC, Gregory RK, Allred DC (1997) Prediction of response to neoadjuvant chemoendocrine therapy in primary breast carcinomas. Clin Cancer Res 3:593-600

68. Mallett S, Timmer A, Sauerbrei W, Altman DG (2010) Reporting of prognostic studies of tumour markers: a review of published articles in relation to REMARK guidelines. $\mathrm{Br} \mathbf{J}$ Cancer 102:173-180

69. Mandard AM, Denoux Y, Herlin P, Duigou F, van De Vijver MJ, Clahsen PC, van Den Broek L, Sahmoud TM, Henry-Amar M, van De Velde CJ (2000) Prognostic value of DNA cytometry in 281 premenopausal patients with lymph node negative breast carcinoma randomized in a control trial: multivariate analysis with Ki-67 index, mitotic count, and microvessel density. Cancer 89:1748-1757

70. Mauriac L, MacGrogan G, Avril A (1999) Neoadjuvant chemotherapy for operable breast carcinoma larger than $3 \mathrm{~cm}$ : a unicentre randomized trial with a 124-month median follow-up. Ann Oncol 10:47-52

71. McShane LM, Altman DG, Sauerbrei W, Taube SE, Gion M, Clark GM (2005) REporting recommendations for tumor MARKer prognostic studies (REMARK). Nat Clin Pract Oncol 2:416-422

72. Michalides R, Tinteren HV, Balkenende A, Vermorken JB, Benraadt J, Huldij J, Diest PV (2002) Cyclin A is a prognostic indicator in early stage breast cancer with and without tamoxifen treatment. Br J Cancer 2:402-408

73. Miller WR, White S, Dixon JM, Murray J, Renshaw L, Anderson TJ (2006) Proliferation, steroid receptors and clinical/ pathological response in breast cancer treated with letrozole. $\mathrm{Br}$ J Cancer 94:1051-1056

74. Moher D, Schulz KF, Altman D (2001) The CONSORT Statement: revised recommendations for improving the quality of reports of parallel-group randomized trials 2001. BMC Med Res Methodol 1:40-45

75. Moher D, Hopewell S, Schulz KF, Montori V, Gotzsche PC, Devereaux PJ, Elbourne D, Egger M, Altman DG (2010) 
CONSORT 2010 explanation and elaboration: updated guidelines for reporting parallel group randomised trials. BMJ 340:c869

76. Molino A, Micciolo R, Turazza M, Bonetti F, Piubello Q, Bonetti A, Nortilli R, Pelosi G, Cetto GL (1997) Ki-67 immunostaining in 322 primary breast cancers: associations with clinical and pathological variables and prognosis. Int $\mathrm{J}$ Cancer 74:433-437

77. Mottolese M, Benevolo M, DM G, Buglioni S, Papaldo P, Nisticò C, Di Filippo F, Vasselli S, Vici P, Botti C (2000) Role of P53 and BCL-2 in high-risk breast cancer patients treated with adjuvant anthracycline-based chemotherapy. J Cancer Res Clin Oncol 126:722-729

78. Nishimura R, Osako T, Okumura Y, Hayashi M, Arima N (2009) Clinical significance of Ki-67 in neoadjuvant chemotherapy for primary breast cancer as a predictor for chemosensitivity and for prognosis. Breast Cancer 17:269-275. doi: 10.1007/s12282-009-0161-5

79. Oakman C, Bessi S, Zafarana E, Galardi F, Biganzoli L, Di Leo A (2009) Recent advances in systemic therapy. New diagnostics and biological predictors of outcome in early breast cancer. Breast Cancer Res 11:205. doi:10.1186/bcr2238

80. Peiró G, Aranda FI, Adrover E, Niveiro M, Alenda C, Payá A, Seguí J (2007) Analysis of HER2 by chromogenic in situ hybridization and immunohistochemistry in lymph node-negative breast carcinoma: prognostic relevance. Hum Pathol 38:26-34

81. Pellikainen MJ, Pekola TT, Ropponen KM, Kataja VV, Kellokoski JK, Eskelinen MJ, Kosma VM (2003) p21WAF1 expression in invasive breast cancer and its association with p53, AP-2, cell proliferation, and prognosis. J Clin Oncol 56:214-220

82. Penault-Llorca F, Abrial C, Raoelfils I, Chollet P, Cayre A, Mouret-Reynier M-A, Thivat E, Mishellany F, Gimbergues P, Durando X (2008) Changes and predictive and prognostic value of the mitotic index, Ki-67, cyclin D1, and cyclo-oxygenase-2 in 710 operable breast cancer patients treated with neoadjuvant chemotherapy. Oncologist 13:1235-1245

83. Penault-Llorca F, Andre F, Sagan C, Lacroix-Triki M, Denoux Y, Verriele V, Jacquemier J, Baranzelli MC, Bibeau F, Antoine M, Lagarde N, Martin AL, Asselain B, Roche H (2009) Ki67 expression and docetaxel efficacy in patients with estrogen receptor-positive breast cancer. J Clin Oncol 27:2809-2815. doi: 10.1200/jco.2008.18.2808

84. Petit T (2004) Comparative value of tumour grade, hormonal receptors, Ki-67, HER-2 and topoisomerase II alpha status as predictive markers in breast cancer patients treated with neoadjuvant anthracycline-based chemotherapy. Eur J Cancer 40:205-211

85. Piccart-Gebhart MJ, Procter M, Leyland-Jones B, Goldhirsch A, Untch M, Smith I, Gianni L, Baselga J, Bell R, Jackisch C et al (2005) Trastuzumab after adjuvant chemotherapy in HER2positive breast cancer. NEJM 353:1659

86. Pierga JY, Leroyer A, Viehl P, Mosseri V, Chevillard S, Magdelénat $\mathrm{H}$ (1996) Long term prognostic value of growth fraction determination by $\mathrm{Ki}-67$ immunostaining in primary operable breast cancer. Breast Cancer Res Treat 37:57-64

87. Pietiläinen T, Lipponen P, Aaltomaa S, Eskelinen M, Kosma VM, Syrjänen K (1996) The important prognostic value of Ki67 expression as determined by image analysis in breast cancer. J Cancer Res Clin Oncol 122:687-692

88. Pinder SE, Wencyk P, Sibbering DM, Bell Ja, Elston CW, Nicholson R, Robertson JF, Blamey RW, Ellis IO (1995) Assessment of the new proliferation marker MIB1 in breast carcinoma using image analysis: associations with other prognostic factors and survival. Br J Cancer 71:146-149
89. Pinto AE, André S, Pereira T, Nóbrega S, Soares J (2001) Prognostic comparative study of S-phase fraction and Ki-67 index in breast carcinoma. J Clin Pathol 54:543-549

90. Pohl G, Rudas M, Taucher S, Stranzl T, Steger GG, Jakesz R, Pirker R, Filipits M (2003) Expression of cell cycle regulatory proteins in breast carcinomas before and after preoperative chemotherapy. Breast Cancer Res Treat 78:97-103

91. Poole CJ, Earl HM, Hiller L, Dunn JA, Bathers S, Grieve RJ, Spooner DA, Agrawal RK, Fernando IN, Brunt AM et al (2006) Epirubicin and cyclophosphamide, methotrexate, and fluorouracil as adjuvant therapy for early breast cancer. NEJM 355:1851-1862

92. Querzoli P, Albonico G, Ferretti S, Rinaldi R, Magri E, Indelli M, Nenci I (1996) MIB-1 proliferative activity in invasive breast cancer measured by image analysis. J Clin Pathol 49:926-930

93. Railo M, Nordling S, von Boguslawsky K, Leivonen M, Kyllonen L, von Smitten K (1993) Prognostic value of Ki-67 immunolabelling in primary operable breast cancer. $\mathrm{Br} \mathrm{J}$ Cancer 68:579-583

94. Rakha EA, El-Sayed ME, Lee AHS, Elston CW, Grainge MJ, Hodi E, Blamey RW, Ellis IO (2008) Prognostic significance of Nottingham histologic grade in invasive breast carcinoma. J Clin Oncol 26:3153-3158

95. Royston P, Altman DG, Sauerbrei W (2006) Dichotomizing continuous predictors in multiple regression: a bad idea. Stat Med 25:127-141. doi:10.1002/sim.2331

96. Rudolph P, Alm P, Heidebrecht HJ, Bolte H, Ratjen V, Baldetorp B, Fernö M, Olsson H, Parwaresch R (1999) Immunologic proliferation marker $\mathrm{Ki}-\mathrm{S} 2$ as prognostic indicator for lymph node-negative breast cancer. J Natl Cancer Inst 91:271-278

97. Rudolph P, MacGrogan G, Bonichon F, Frahm SO, de Mascarel I, Trojani M, Durand M, Avril A, Coindre JM, Parwaresch R (1999) Prognostic significance of Ki-67 and topoisomerase II $\alpha$ expression in infiltrating ductal carcinoma of the breast. Breast Cancer Res Treat 55:61-71

98. Simon RM, Paik S, Hayes DF (2009) Use of archived specimens in evaluation of prognostic and predictive biomarkers. J Natl Cancer Inst 101:1446-1452

99. Smith IE, Dowsett M, Ebbs SR, Dixon JM, Skene A, Blohmer JU, Ashley SE, Francis S, Boeddinghaus I, Walsh G (2005) Neoadjuvant treatment of postmenopausal breast cancer with anastrozole, tamoxifen, or both in combination: the Immediate Preoperative Anastrozole, Tamoxifen, or Combined with Tamoxifen (IMPACT) multicenter double-blind randomized trial. J Clin Oncol 23:5108-5116

100. Stuart-Harris R, Caldas C, Pinder SE, Pharoah P (2008) Proliferation markers and survival in early breast cancer: a systematic review and meta-analysis of 85 studies in 32,825 patients. Breast $17: 323-334$

101. Sturgeon CM, Duffy MJ, Stenman UH, Lilja H, Brunner N, Chan DW, Babaian R, Bast RC, Dowell B, Esteva FJ, Haglund C, Harbeck N, Hayes DF, Holten-Andersen M, Klee GG, Lamerz R, Looijenga LH, Molina R, Nielsen HJ, Rittenhouse H, Semjonow A, Shih IM, Sibley P, Soletormos G, Stephan C, Sokoll L, Hoffman BR, Diamandis EP (2008) National Academy of Clinical Biochemistry Laboratory Medicine practice guidelines for use of tumor markers in testicular, prostate, colorectal, breast, and ovarian cancers. Clin Chem 54:e11-e79. doi:10.1373/clinchem.2008.105601

102. Tanei T, Shimomura A, Shimazu K, Nakayama T, Kim SJ, Iwamoto T, Tamaki Y, Noguchi S (2011) Prognostic significance of Ki67 index after neoadjuvant chemotherapy in breast cancer. Eur J Surg Oncol 37:155-161. doi:10.1016/j.ejso.2010. 10.009

103. Taylor WC, Muss HB (2010) Recent advances: adjuvant therapy for older women with breast cancer. Cancer J 16:289-293 
104. Thor AD, Liu S, Moore II, Dan H, Edgerton SM (1999) Comparison of mitotic index, in vitro bromodeoxyuridine labeling, and MIB-1 assays to quantitate proliferation in breast cancer. J Clin Oncol 17:470-477

105. Ueda S, Kondoh N, Tsuda H, Yamamoto S, Asakawa H, Fukatsu K, Kobayashi T, Yamamoto J, Tamura K, Ishida J, Abe Y, Yamamoto M, Mochizuki H (2008) Expression of centromere protein $\mathrm{F}$ (CENP-F) associated with higher FDG uptake on PET/ $\mathrm{CT}$, detected by cDNA microarray, predicts high-risk patients with primary breast cancer. BMC Cancer 8:384. doi:10.1186/ 1471-2407-8-384

106. Untch M, Gelber RD, Jackisch C, Procter M, Baselga J, Bell R, Cameron D, Bari M, Smith I, Leyland-Jones B, de Azambuja E, Wermuth P, Khasanov R, Feng-Yi F, Constantin C, Mayordomo JI, Su CH, Yu SY, Lluch A, Senkus-Konefka E, Price C, Haslbauer FT, Srimuninnimit V, Colleoni M, Coates AS, PiccartGebhart MJ, Goldhirsch A (2008) Estimating the magnitude of trastuzumab effects within patient subgroups in the HERA trial. Ann Oncol 19:1090-1096

107. Urruticoechea A, Smith IE, Dowsett M (2005) Proliferation marker Ki-67 in early breast cancer. J Clin Oncol 23:7212-7220

108. Viale G, Giobbie-Hurder A, Regan MM, Coates AS, Mastropasqua MG, Dell' Orto P, Maiorano E, MacGrogan G, Braye SG, Ohlschlegel C, Neven P, Orosz Z, Olszewski WP, Knox F, Thürlimann B, Price KN, Castiglione-Gertsch M, Gelber RD, Gusterson BA, Goldhirsch A (2008) Prognostic and predictive value of centrally reviewed Ki-67 labeling index in postmenopausal women with endocrine-responsive breast cancer: results from Breast International Group Trial 1-98 comparing adjuvant tamoxifen with letrozole. J Clin Oncol 26:5569-5575

109. Viale G, Regan MM, Mastropasqua MG, Maffini F, Maiorano E, Colleoni M, Price KN, Golouh R, Perin T, Brown RW, Kovács A, Pillay K, Ohlschlegel C, Gusterson Ba, Castiglione-Gertsch M, Gelber RD, Goldhirsch A, Coates AS (2008) Predictive value of tumor Ki-67 expression in two randomized trials of adjuvant chemoendocrine therapy for node-negative breast cancer. J Natl Cancer Inst 100:207-212

110. von Minckwitz G, Sinn H-P, Raab G, Loibl S, Blohmer J-U, Eidtmann H, Hilfrich J, Merkle E, Jackisch C, Costa SD, Caputo A, Kaufmann M (2008) Clinical response after two cycles compared to HER2, Ki-67, p53, and bcl-2 in independently predicting a pathological complete response after preoperative chemotherapy in patients with operable carcinoma of the breast. Breast Cancer Res 10:R30

111. Weigel MT, Dowsett M (2010) Current and emerging biomarkers in breast cancer: prognosis and prediction. Endocr Relat Cancer 17:R245-R262

112. Whitfield ML, George LK, Grant GD, Perou CM (2006) Common markers of proliferation. Nat Rev Cancer 6:99-106. doi: 10.1038/nrc1802

113. Wirapati P, Sotiriou C, Kunkel S, Farmer P, Pradervand S, Haibe-Kains B, Desmedt C, Ignatiadis M, Sengstag T, Schutz F, Goldstein DR, Piccart M, Delorenzi M (2008) Meta-analysis of gene-expression profiles in breast cancer: toward a unified understanding of breast cancer sub-typing and prognosis signatures. Breast Cancer Res 10:R65. doi:10.1186/bcr2124

114. Wong SCC, Chan JKC, Lo ESF, Chan AKC, Wong MCK, Chan CML, Lam MYY, Chan ATC (2007) The contribution of bifunctional SkipDewax pretreatment solution, rabbit monoclonal antibodies, and polymer detection systems in immunohistochemistry. Arch Pathol Lab Med 131:1047-1055

115. Yerushalmi R, Woods R, Ravdin PM, Hayes MM, Gelmon KA (2010) Ki67 in breast cancer: prognostic and predictive potential. Lancet Oncol 11:174-183

116. Zabaglo L, Salter J, Anderson H, Quinn E, Hills M, Detre S, A'Hern R, Dowsett M (2010) Comparative validation of the SP6 antibody to Ki67 in breast cancer. J Clin Pathol 63:800-804. doi:10.1136/jcp.2010.077578 